\title{
Oral Delivery of Novel Recombinant Lactobacillus Elicit High Protection against Staphylococcus aureus Pulmonary and Skin Infections
}

\author{
Na Pan ${ }^{1}$, Bohui Liu ${ }^{1}$, Xuemei Bao ${ }^{1}$, Haochi Zhang ${ }^{1}$, Shouxin Sheng ${ }^{1}$, Yanchen Liang ${ }^{1}$, Haiting Pan ${ }^{1,2}$ \\ and Xiao Wang $1, * \mathbb{D}$ \\ 1 State Key Laboratory of Reproductive Regulation and Breeding of Grassland Livestock, \\ Inner Mongolia University, Hohhot 010070, China; 22008032@mail.imu.edu.cn (N.P.); \\ 31808136@mail.imu.edu.cn (B.L.); 31908096@mail.imu.edu.cn (X.B.); 21908028@mail.imu.edu.cn (H.Z.); \\ shouxins1230@mail.imu.edu.cn (S.S.); yanchenliang@mail.imu.edu.cn (Y.L.); $131985999 @$ imu.edu.cn (H.P.) \\ 2 Basic Medical College, Inner Mongolia Medical University, Hohhot 010110, China \\ * Correspondence: wangxiao@imu.edu.cn
}

\section{check for} updates

Citation: Pan, N.; Liu, B.; Bao, X.; Zhang, H.; Sheng, S.; Liang, Y.; Pan, H.; Wang, X. Oral Delivery of Novel Recombinant Lactobacillus Elicit High Protection against Staphylococcus aureus Pulmonary and Skin Infections. Vaccines 2021, 9, 984. https:/ / doi.org/10.3390/vaccines9090984

Academic Editors: Martin J. D'Souza, Mohammad N. Uddin, Rikhav Gala and Bernadette D'Souza

Received: 6 August 2021

Accepted: 30 August 2021

Published: 3 September 2021

Publisher's Note: MDPI stays neutral with regard to jurisdictional claims in published maps and institutional affiliations.

Copyright: (c) 2021 by the authors. Licensee MDPI, Basel, Switzerland. This article is an open access article distributed under the terms and conditions of the Creative Commons Attribution (CC BY) license (https:// creativecommons.org/licenses/by/ $4.0 /)$.

\begin{abstract}
Staphylococcus aureus is a leading cause of nosocomial and community-associated infection worldwide; however, there is no licensed vaccine available. S. aureus initiates infection via the mucosa; therefore, a mucosal vaccine is likely to be a promising approach against $S$. aureus infection. Lactobacilli, a non-pathogenic bacterium, has gained increasing interest as a mucosal delivery vehicle. Hence, we attempted to develop an oral $S$. aureus vaccine based on lactobacilli to cushion the stress of drug resistance and vaccine needs. In this study, we designed, constructed, and evaluated recombinant Lactobacillus strains synthesizing $S$. aureus nontoxic mutated $\alpha$-hemolysins $\left(\mathrm{Hla}_{\mathrm{H} 35 \mathrm{~L}}\right)$. The results from animal clinical trials showed that recombinant Lactobacillus can persist for at least $72 \mathrm{~h}$ and can stably express heterologous protein in vivo. Recombinant L. plantarum WXD234 (pNZ8148Hla) could induce robust mucosal immunity in the GALT, as evidenced by a significant increase in IgA and IL-17 production and the strong proliferation of T-lymphocytes derived from Peyer's patches. WXD234 (pNZ8148-Hla) conferred up to $83 \%$ protection against $S$. aureus pulmonary infection and significantly reduced the abscess size in a $S$. aureus skin infection model. Of particular interest is the sharp reduction of the protective effect offered by WXD234 (pNZ8148-Hla) vaccination in $\gamma \delta \mathrm{T}$ cell-deficient or IL-17-deficient mice. In conclusion, for the first time, genetically engineered Lactobacillus WXD234 (pNZ8148-Hla) as an oral vaccine induced superior mucosal immunity, which was associated with high protection against pulmonary and skin infections caused by S. aureus. Taken together, our findings suggest the great potential for a delivery system based on lactobacilli and provide experimental data for the development of mucosal vaccines for $S$. aureus.
\end{abstract}

Keywords: Staphylococcus aureus; oral vaccine; Lactobacillus; mucosal delivery

\section{Introduction}

Staphylococcus aureus is normally a non-harmful commensal bacterium in humans and other mammals, but occasionally becomes invasive and produces serious diseases, including sepsis, infective endocarditis, pleurisy, septic arthritis, skin infection, and soft tissue infection [1]. Routine, indiscriminate use of antibiotics during recent decades has resulted in the increasing development of drug-resistant strains, especially methicillinresistant S. aureus (MRSA) and vancomycin-resistant S. aureus (VRSA), characterized by wide spreading ability, high pathogenicity, multidrug resistance, and limited or no options for therapeutic intervention [2,3]. Morbidity and mortality due to serious diseases and their sequelae are high despite use of antibiotics to which these strains are susceptible [4]. Vaccination is a promising method, in theory, for preventing and combating S. aureus infections without risking the development of drug-resistant strains [5]. However, notwithstanding 
several decades of intensive research by numerous first-class research institutions, a safe and consistently effective vaccine against $S$. aureus is still not available-and is urgently needed [6-8].

Host mucosal tissues such as gut and skin are cohabitated. S. aureus normally colonizes mucous membranes and skin in a non-harmful manner but can quickly take advantage of opportunities to invade adjoining tissues if these barriers are overcome, in which case, mucosal immune response is an important first line of defense. The delivery of a vaccine directly to mucosa is therefore likely to help stimulate protective immunity at the invasion site. Oral vaccines can stimulate protective immunity at the different invasion site, for instance, the Oral Polio Vaccine ${ }^{\circledR}$ [9] and Dukoral ${ }^{\circledR}[10]$ take action in the intestine and oral influenza vaccines [11,12] and Streptococcus pneumoniae vaccines are active in the respiratory tract [13]. Studies to date on anti-S. aureus mucosal vaccines have been restricted to those based on live bacteria [14], S. aureus antigens [15,16], nanoparticles [17], or bacterial outer membrane vehicles [18]. The effectiveness and safety of such vaccines remain to be confirmed.

Lactobacillus strains are important members of the human and animal microbiome and have gained wide-spread attention because of their diverse effects on host health. Several features of lactobacilli make them strong candidates as vectors for oral delivery to the mucosa of compounds of pharmaceutical interest, particularly vaccines and immunomodulators. Lactobacilli have received the "generally recognized as safe" (GRAS) designation from the US FDA (GRAS notice website: https: / / www.accessdata.fda.gov / scripts / fdcc / ?set=GRASNotices (accessed on 14 June 2021)) and have been widely utilized in food and pharmaceutical industries for decades. Strains of the genus Lactobacillus are resistant to toxic effects of bile acid and are persistent in the gastrointestinal tract [19]. Prototypes of modified Lactobacillus strains are being developed, and recombinant forms of various Lactobacillus species have been used as a basis for vaccines against Streptococcus pneumoniae [20], transmissible gastroenteritis coronavirus [21], Bacillus anthracis [22,23], rotavirus [24], and tetanus toxin [25]. The possible utilization of lactobacilli as a delivery system for a $S$. aureus antigen has not been investigated. Hence, we here describe a promising strategy along this line for the generation of an effective $S$. aureus oral vaccine utilizing lactobacilli as a delivery vector.

Previously, two lactobacilli possessing tremendous probiotic properties were isolated from dairy products and were identified as L. kefiri SXJ29 (GenBank: MZ501823.1) and L. plantarum WXD234 (GenBank: MZ501859.1) [26]. In this study, we described new anti-S. aureus oral vaccines based on $\mathrm{Hla}_{\mathrm{H} 35 \mathrm{~L}}[27,28]$-expressing lactobacilli strains. The efficacy of recombinant Lactobacillus WXD234 (pNZ8148-Hla) was comprehensively evaluated using two mouse models suitable for accurately monitoring the progression of several diseases, including pulmonary and skin infections. These results suggest a great potential for a delivery system based on lactobacilli and provide experimental data for the development of $S$. aureus mucosal vaccines.

\section{Materials and Methods}

\subsection{Bacterial Strains and Growth Conditions}

The detail of all strains and plasmids used in this study are listed in Table 1. Lactobacillus strains were grown in de Man, Rogosa and Sharpe (MRS) (HuanKai Microbial; Guangdong, China) broth at $37^{\circ} \mathrm{C}$ in anaerobic conditions for $24 \mathrm{~h}$. The Lactobacillus derivatives were cultured with the addition of chloramphenicol $(20 \mu \mathrm{g} / \mathrm{mL}$; antibiotic) and nisin $(5 \mathrm{ng} / \mathrm{mL}$; inducer). S. aureus USA300 was cultured in Luria-Bertani (LB) medium at $37^{\circ} \mathrm{C}$ in aerobic conditions for $16 \mathrm{~h}$.

\subsection{Experimental Animals and Ethics Statement}

Specific-pathogen-free (SPF) female wild-type (WT) C57BL/6 mice were purchased from the Beijing Vital River Laboratory Animal Technology Co. (Beijing, China). TCR $\gamma / \delta$-deficient mice (JAX Stock number: 003288) and IL-17A-deficient mice (NCBI Stock 
number: 16171) of C57BL/6N background were kindly donated by Dr. Z. Yin (College of Life Sciences, Jinan University, Guangdong, China). All of the animal-related experimental protocols applied in this study were conducted under the standards of the Ethics Committee of Inner Mongolia Medical University (SCXK2016-0001).

\subsection{Construction of Hla $\mathrm{H}_{35 \mathrm{~L}}$ Cell Surface Display Lactobacillus Based on SXJ29 and WXD234}

The design strategy and construction process of the recombinant plasmid pNZ8148Hla are shown in Figure 1a. A 90-bp fragment encoding L. brevis S-layer 30-a.a. signal peptide [29] was ligated to the front of the $S$. aureus antigen $\mathrm{Hla}_{\mathrm{H} 35 \mathrm{~L}}$. The $h l a_{\mathrm{H} 35 \mathrm{~L}}$ gene was designed based on the L. plantarum codon bias and was artificially synthesized by GenScript Biotech (Nanjing, China). The fragment was ligated into the EcoRV restriction site in plasmid pUC57 to generate the cloning plasmid pUC57-Hla. The $s p-h l a_{H 35 L}$ fragment obtained by the digestion of pUC57-Hla with NcoI and KpnI was inserted into the Lactococcus lactis inducible expression plasmid pNZ8148 to generate the recombinant expression plasmid pNZ8148-Hla. Competent Lactobacillus were prepared through the inoculation (1:25) of SXJ29 overnight culture in MRS containing 1\% glycine and of WXD234 in MRS containing $0.3 \mathrm{M}$ sucrose. SXJ29 bacteria were cultured until the $\mathrm{OD}_{600}$ value was from $0.6-0.8$ and were collected by centrifugation and washed $2 \times$ with $10 \%$ glycerol $(v / v)$. WXD234 were cultured until the $\mathrm{OD}_{600}$ value ranged from $0.3-0.4$ and were collected by centrifugation and washed $2 \times$ with $0.5 \mathrm{M}$ saccharose, $0.5 \mathrm{mM} \mathrm{KH}_{2} \mathrm{PO}_{4}$, and $0.5 \mathrm{mM} \mathrm{MgCl}_{2}$. Each strain was suspended in its washing buffer (1:50), and the recombinant plasmid pNZ8148-Hla was introduced immediately into competent Lactobacillus by electroporation. Clones with the insertion of the target gene were screened by identifying antibiotic-resistant Lactobacillus by enzyme restriction, PCR, and sequencing. Positive clones of SXJ29 (pNZ8148-Hla) and WXD234 (pNZ8148-Hla) were frozen $\left(-80^{\circ} \mathrm{C}\right.$ ) in MRS containing $15 \%$ glycerol.

$\mathrm{Hla}_{\mathrm{H} 35 \mathrm{~L}}$ expression in SXJ29 and WXD234 was assayed by Western blotting and confocal laser scanning microscopy (CLSM). SXJ29 (pNZ8148-Hla), SXJ29 (pNZ8148), WXD234 (pNZ8148-Hla), and WXD234 (pNZ8148) were cultured in MRS at $37^{\circ} \mathrm{C}$ until the $\mathrm{OD}_{600}$ value ranged 0.6-0.8, induced with $5 \mathrm{ng} / \mathrm{mL}$ nisin (Sigma-Aldrich; St. Louis, MO, USA), and cultured overnight. Cells were washed $2 \times$ with $0.01 \mathrm{M}$ phosphate-buffered saline (PBS; Coolaber Science \& Technology Co.; Beijing, China), lysed in PBS containing $10 \mathrm{mg} / \mathrm{mL}$ lysozyme (Coolaber) for $30 \mathrm{~min}$ at $37^{\circ} \mathrm{C}$, sonicated at $150 \mathrm{~W}$ for $10 \mathrm{~min}$, and boiled for $10 \mathrm{~min}$. Lysates were subjected to 12\% SDS-PAGE followed by Western blotting analysis using mouse anti-Hla $\mathrm{H}_{35 \mathrm{~L}} \mathrm{mAb}$ (GenScript Biotech) as primary the antibody and HRP-conjugated goat anti-mouse IgG (Proteintech; Rosemont, IL, USA) as the secondary antibody. The location of $\mathrm{Hla}_{\mathrm{H} 35 \mathrm{~L}}$ was assayed through immunofluorescence assay as follows: the cells were collected, washed $3 \times$ with PBS, blocked for $1 \mathrm{~h}$ with $3 \%$ BSA in PBS, stained with anti-Hla $\mathrm{H}_{35 \mathrm{~L}} \mathrm{mAb}$ (GenScript Biotech) for $1 \mathrm{~h}$, incubated with Cy3-conjugated goat anti-mouse IgG (Sangon, Biotech; Beijing, China) for $1 \mathrm{~h}$, and incubated again with antigen-free strains SXJ29 (pNZ8148) and WXD234 (pNZ8148) as a negative control. The red fluorescent signal was acquired using a $550 \mathrm{~nm}$ excitation laser line and was detected at 560 to $600 \mathrm{~nm}$, and photographs were taken with a Nikon camera.

We measured the physiological indexes of SXJ29 (pNZ8148-Hla) and WXD234 (pNZ8148-Hla), i.e., including growth curves, growth states at various temperatures (16, $\left.23,30,37,42,49,56^{\circ} \mathrm{C}\right)$, $\mathrm{pH}$ values $(2.0,3.0,4.0,5.0,6.0,7.0,8.0,9.0), \mathrm{NaCl}$ concentrations $(0,1,3,5,7,9,11 \%)$, acid resistance, and bile tolerance [30]. The hereditary stability of recombinant strain detection was conducted according to a published protocol [31]. In brief, the recombinant strains serially transferred the cultures after $24 \mathrm{~h}$ of incubation in MRS medium containing chloramphenicol at $37^{\circ} \mathrm{C}$ (20 generations), and the plasmid was extracted to confirm the presence of recombinant plasmids in each strain. 
a

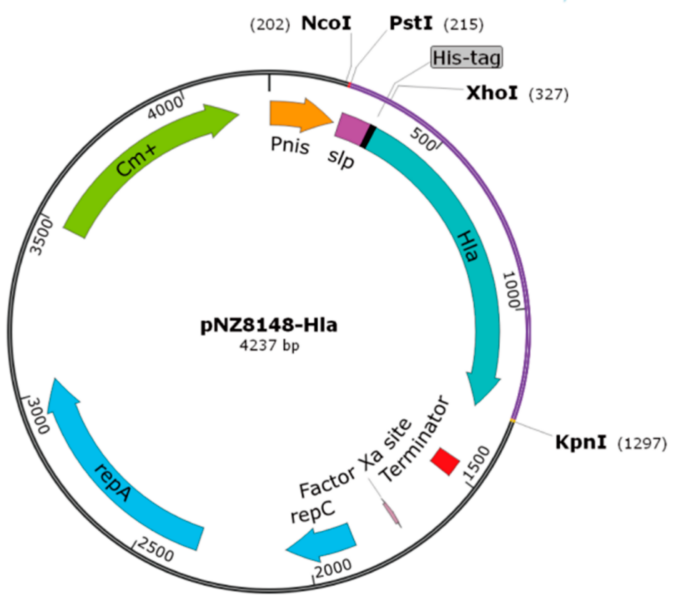

b

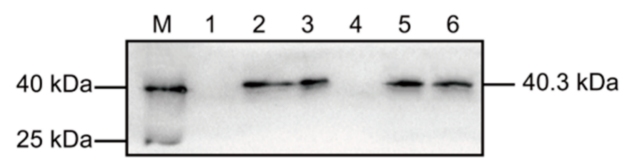

C

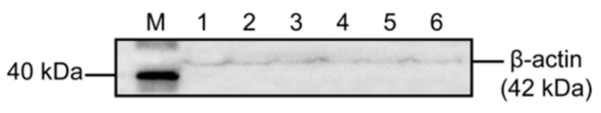

d

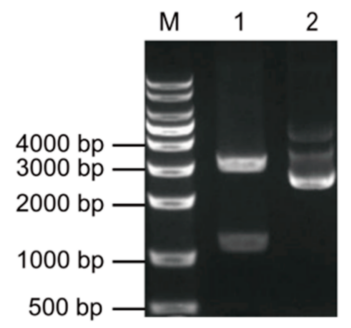

e

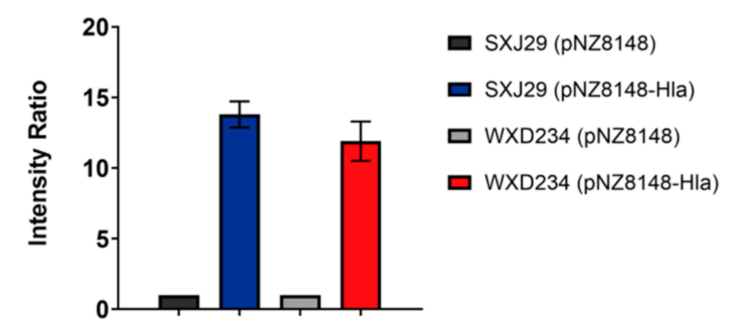

f $\mathrm{CLSM}$

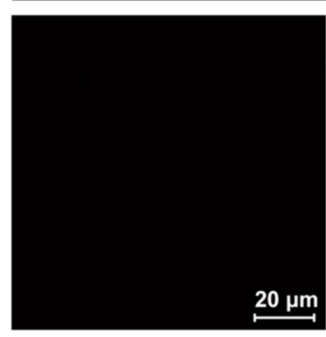

SXJ29 (pNZ8148)

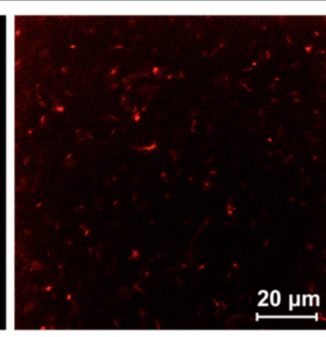

SXJ29 (pNZ8148-Hla)

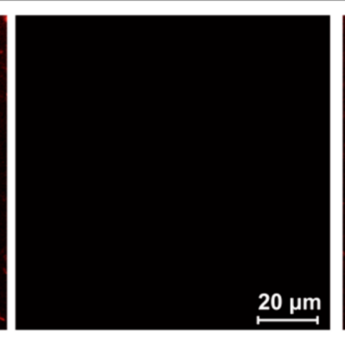

WXD234 (pNZ8148)

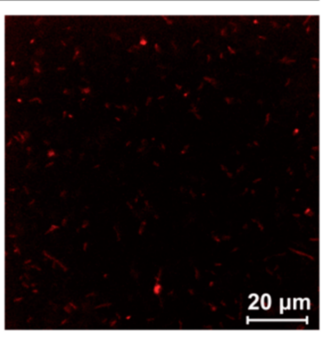

WXD234 (pNZ8148-Hla)

Figure 1. Construction of the pNZ8148-Hla plasmid and the expression of Hla $\mathrm{H}_{35 \mathrm{~L}}$ in SXJ29 and WXD234. (a) Genetic engineering using pNZ8148 (schematic). (d) Full-length coding sequence of Hla $\mathrm{H}_{35 \mathrm{~L}}$ was cloned into the pNZ8148 plasmid and was modified with a signal peptide from L. brevis and a His-tag. The recombinant pNZ8148-Hla plasmid was identified by restriction analysis. DNA markers (Lane M), pNZ8148-Hla (Lane 2), and pNZ8148-Hla were digested with PstI and KpnI (lane 1). Hla $\mathrm{H}_{35 \mathrm{~L}}$ expression on recombinant SXJ29/WXD234 (pNZ8148-Hla) subjected to nisin induction was measured by Western blotting analysis. Cell extracts were prepared and analyzed by means of Western blotting using anti-Hla $\mathrm{H} 35 \mathrm{~L}$ mAb (b) or anti- $\beta$-actin mAb (c). Left: molecular masses of pre-stained marker proteins. Protein markers (lane M), SXJ29 (pNZ8148) (Lane 1), SXJ29 (pNZ8148-Hla) (Lane 2, 3), WXD234 (pNZ8148) (Lane 4), WXD234 (pNZ8148-Hla) (Lane 5, 6). (e) Intensity ratio of $\mathrm{Hla}_{\mathrm{H} 35 \mathrm{~L}}$ expression in SXJ29 and WXD234. (f) CLSM detection of Hla $\mathrm{H} 35 \mathrm{~L}$ expression on SXJ29/WXD234 (pNZ8148-Hla).

\subsection{Colonization and Persistence of Recombinant Lactobacillus in the Intestine}

To monitor the colonization and persistence of recombinant Lactobacillus in vivo, EGFP-expressing Lactobacillus SXJ29 (pNZ8148-EGFP) and WXD234 (pNZ8148-EGFP) were constructed the same as described above. Mice were divided into SXJ29 (pNZ8148-EGFP) $(n=15), \mathrm{WXD} 234$ (pNZ8148-EGFP) $(n=15)$, and control groups $(n=3)$. All of the mice were orally inoculated with $2 \times 10^{9}$ colony-forming units (CFUs) of bacteria or PBS, and intragastric administration was performed for three consecutive days. Prior to intragastric administration, recombinant Lactobacillus were cultured in MRS until the $\mathrm{OD}_{600}$ value ranged from $0.6-0.8$, induced with $5 \mathrm{ng} / \mathrm{mL}$ nisin for $6 \mathrm{~h}$, washed with PBS, and concentration adjusted to $10^{10} \mathrm{CFU} / \mathrm{mL}$. The intestines (duodenum, jejunum, ileum, cecum, and 
colon) were collected at $6,12,24,48$, and $72 \mathrm{~h}$ after the last intragastric administration. To assess the mucosal-associated bacteria, the entire length of the intestine was flushed with ice-cold sterile PBS that removed and collected the luminal contents and loosely adherent bacteria. Then, the intestinal tissues were homogenized using a tissue homogenizer (Analytikjena; Yena, Germany) in $5 \mathrm{~mL}$ of PBS containing 0.1\% Tween-20 (Coolaber) (PBST). Samples from the luminal contents and tissue homogenate were serially diluted in PBS and were cultured on MRS plates containing chloramphenicol at $37^{\circ} \mathrm{C}$ for $48 \mathrm{~h}$, and the bacterial colonies were counted using a Scan 300 automated colony counter (Interscience; Saint Nom la Bretêche, France). The intestinal contents of each group at $6 \mathrm{~h}$ were mounted on slides for direct observation with fluorescence microscopy (TI-DH inverted fluorescence Microscopy, Nikon) equipped with a GFP filter set (excitation $470 \mathrm{~nm}$; emission $505 \mathrm{~nm}$ to $530 \mathrm{~nm}$ ). Photographs were taken with a Nikon camera.

\subsection{Vaccination}

The preparation of the bacteria prior to intragastric administration was same as described above. All of the mice were orally inoculated with $2 \times 10^{9}$ CFUs of bacteria or PBS. The immunization protocol was conducted over three consecutive days: days 1 , 2 , and 3 . Booster immunization was administered on days 14,15 , and 16 , and a second booster was given on days 28, 29, and 30 .

\subsection{Determination of $\operatorname{IgG}$ and $\operatorname{Ig} A$ Levels by ELISA}

Levels of $\mathrm{Hla}_{\mathrm{H} 35 \mathrm{~L}}$-specific IgG in serum and $\mathrm{IgA}$ in the intestinal mucus were determined by enzyme-linked immunosorbent assay (ELISA). Sera and intestinal mucus were collected from three mice that were selected randomly from the vaccinated mice on days 1 , $7,14,21,28,35$, and 42 . Serum samples were collected from the retroorbital plexus, kept at $37{ }^{\circ} \mathrm{C}$ for $2 \mathrm{~h}$ for clotting, centrifuged, and stored at $-20{ }^{\circ} \mathrm{C}$ until testing. The intestinal mucus (each $\sim 0.2 \mathrm{~g}$ ) was separated, suspended with $500 \mu \mathrm{L}$ HEPES buffer (Thermo Fisher Scientifics; Waltham, MA, USA), and centrifuged $(3000 \times g, 15 \mathrm{~min})$. Supernatant was stored at $-20{ }^{\circ} \mathrm{C}$ until it was assayed. Next, 96-well MICROLON ELISA plates were coated with $0.5 \mu \mathrm{g} / \mathrm{mL}$ purified $\mathrm{Hla}_{\mathrm{H} 35 \mathrm{~L}}$ protein (obtained from the E. coli expression system constructed by our previous work) overnight at $4{ }^{\circ} \mathrm{C}$, washed $3 \times$ with PBS containing 0.05\% Tween-20 (PBST), blocked with 5\% BSA for $2 \mathrm{~h}$ at $37^{\circ} \mathrm{C}$, and washed $3 \times$ with PBST. Samples (serum at 1:50 dilution; intestinal mucus at 1:10 dilution) were added and incubated for $2 \mathrm{~h}$ at $37^{\circ} \mathrm{C}$, washed 5x with PBST, added with HRP-conjugated goat anti-mouse IgG or IgA (Proteintech) for $2 \mathrm{~h}$ at $37^{\circ} \mathrm{C}$, washed $5 \times$ with PBST. TMB single-component substrate solution (Solarbio; Beijing, China) was then employed to develop the color, and absorbance was measured as $\mathrm{OD}_{450}$.

\subsection{T Cell Proliferation Assay}

Spleens and Peyer's patches were removed from three mice in each group on day 35, and we established single-cell suspensions, as described previously [32]. Red blood cells were lysed in hypotonic buffers, and the suspensions were cultivated in $75 \mathrm{~cm}^{2}$ flasks in a $5 \% \mathrm{CO}_{2}$ incubator for the following T-lymphocyte proliferation assay. In brief, a $100 \mu \mathrm{L}$ cell suspension $\left(\sim 10^{5}\right.$ cells $\left./ \mathrm{mL}\right)$ was incubated in a 96-well plate, which was stimulated by purified $\mathrm{Hla}_{\mathrm{H} 35 \mathrm{~L}}$ protein (final concentration $20 \mu \mathrm{g} / \mathrm{mL}$ ) (positive control: $10 \mu \mathrm{g} / \mathrm{mL}$ concanavalin A (ConA); negative control: RPMI 1640 medium) and was cultured for $72 \mathrm{~h}$ at $37{ }^{\circ} \mathrm{C}$ in a $5 \% \mathrm{CO}_{2}$ incubator. T-lymphocyte proliferation was determined by Cell Titer 96 AQueous One Solution Cell Proliferation Assay (MTS) (Promega Corp.; Madison, WI, USA), with a determined absorbance of $\mathrm{OD}_{490}$. The stimulation index (SI) was calculated as the OD value of the stimulated cells divided by the OD value of the unstimulated control cells [33]. 


\subsection{Cytokine Level Assay}

Intestinal tissues were collected from three mice that had been randomly selected from the vaccinated mice on day 35 , suspended with $500 \mu \mathrm{L} 0.1 \%$ PBST, and homogenized by a tissue homogenizer. Cytokine interleukin 2 (IL-2), IL-4, IL-10, IL-17 and interferon $\gamma$ (IFN- $\gamma$ ) in the supernatant were assayed by an ELISA kit (R \& D Systems; Minneapolis, MN, USA). Methods were essentially the same as for antibody detection.

\subsection{Mouse Model of S. aureus-Induced Pulmonary Infection}

Vaccinated mice (female WT, TCR $\gamma / \delta$-deficient and IL-17A-deficient C57BL/6) were anesthetized by an intraperitoneal (i.p.) injection of ketamine-xylazine (KX) and were intranasally inoculated with S. aureus USA300 at concentration $5 \times 10^{9} \mathrm{CFUs} / 40 \mu \mathrm{L} / \mathrm{mouse}$ to initiate pulmonary infection on day 36 . Survival and health status were monitored and recorded during a 72-h period following the challenge onset for the mice in each group $(n=10)$. For bacteriological and histological analyses, vaccinated mice were inoculated with $S$. aureus USA300 at concentration $5 \times 10^{8} \mathrm{CFUs} / 40 \mu \mathrm{L} /$ mouse on day $36(n=10)$. Following the challenge, the right lungs were removed at $48 \mathrm{~h}$ by thoracotomy, weighed, and homogenized. Serial dilutions of $100 \mu \mathrm{L}$ tissue homogenate were placed on mannitol salt agar (MSA) plates (HuanKai Microbial Sci. \& Tech. Co.; Guangdong, China), incubated overnight at $37^{\circ} \mathrm{C}$, and the bacterial colonies were counted using a Scan 300 automated colony counter. The left lungs were fixed, paraffin-embedded, sectioned $(4-6 \mu \mathrm{m})$, stained with H\&E, and evaluated by means of light microscopy (Olympus; Shinjuku, Japan). A total of three fields were examined, and the inflammation index was calculated as (number of inflammatory cells in visual field/total number of cells in field) $\times 100 \%$.

\subsection{Mouse Model of S. aureus-Induced Skin Infection}

The vaccinated mice (female WT and TCR $\gamma / \delta$-deficient C57BL/6) were anesthetized, inoculated by dorsal s.c. injection with $5 \times 10^{8} \mathrm{CFUs} / 50 \mu \mathrm{L} /$ mouse of $S$. aureus USA300, and monitored daily for 28 days for mass and abscess formation $(n=6)$. The sizes of the abscesses and the associated overlying dermonecrotic lesions were determined by a standard equation: Area $(\mathrm{A})=(\pi / 2) \times$ length $\times$ width. For counting of $S$. aureus CFUs in skin abscess lesions, the animals were euthanized 1 day after inoculation, the abscesses were removed and homogenized in PBS, and the CFUs were counted by plating serially diluted samples on tryptic soy agar at $37^{\circ} \mathrm{C}$ and by allowing them to grow for $24 \mathrm{~h}(n=3)$. The skin tissues were fixed, paraffin-embedded, sectioned $(4-6 \mu \mathrm{m})$, and stained with $\mathrm{H}$ \& $\mathrm{E}(n=3)$.

\subsection{Statistical Analysis}

Data were analyzed using the software program GraphPad Prism 8 (San Diego, CA, USA) and were presented as the mean \pm SD from the three replicates for each experiment repeated $3 \times$. Kaplan-Meier survival analysis was performed, and Log-rank (MantelCox) tests were used to make the comparisons between the two groups. Other data were statistically analyzed by a $t$-test. Differences with $p<0.05$ and $p<0.01$ were considered to be significant and highly significant, respectively.

\section{Results}

\subsection{Cell Surface Display System for Hla ${ }_{\mathrm{H} 35 \mathrm{~L}}$ Expression in Transformed Lactobacillus}

We constructed $\mathrm{Hla}_{\mathrm{H} 35 \mathrm{~L}}$ cell surface display Lactobacillus using pNZ8148 and a strategy for the construction of pNZ8148-Hla, which are shown schematically in Figure 1a. The recombinant plasmid pNZ8148-Hla was constructed successfully (Figure 1d) and was introduced into SXJ29 and WXD234 by electroporation. SXJ29 (pNZ8148-Hla) and WXD234 (pNZ8148-Hla) lysates were analyzed by Western blotting. Specific signals were detected at molecular mass $40.3 \mathrm{kDa}$ (Figure $1 \mathrm{~b}$ ), which is consistent with $\mathrm{Hla}_{\mathrm{H} 35 \mathrm{~L}}$. Thus, the S. aureus antigen gene $h \mathrm{la}_{\mathrm{H} 35 \mathrm{~L}}$ was expressed successfully in SXJ29 and WXD234. The location of $\mathrm{Hla}_{\mathrm{H} 35 \mathrm{~L}}$ was analyzed by CLSM, with SXJ29 (pNZ8148) and WXD234 (pNZ8148) as 
negative controls. Visible red fluorescence under green light excitation was observed for SXJ29 (pNZ8148-Hla) and WXD234 (pNZ8148-Hla) but not for the negative control strains (Figure 1f). This CLSM finding indicates that $\mathrm{Hla}_{\mathrm{H} 35 \mathrm{~L}}$ was successfully expressed on the cell surface of lactobacilli.

Recombinant Lactobacillus and WT strains did not differ notably in terms of growth curves (Figure 2a), growth status at various temperatures (Figure 2b), $\mathrm{pH}$ value (Figure 2c), or $\mathrm{NaCl}$ content (Figure 2d). Recombinant Lactobacillus retained acid (Figure 2e) and bile salt resistance properties (Figure 2f), and plasmid pNZ8148-Hla showed stabilized inheritance of at least $20 \mathrm{~d}$ (Figure 2g).
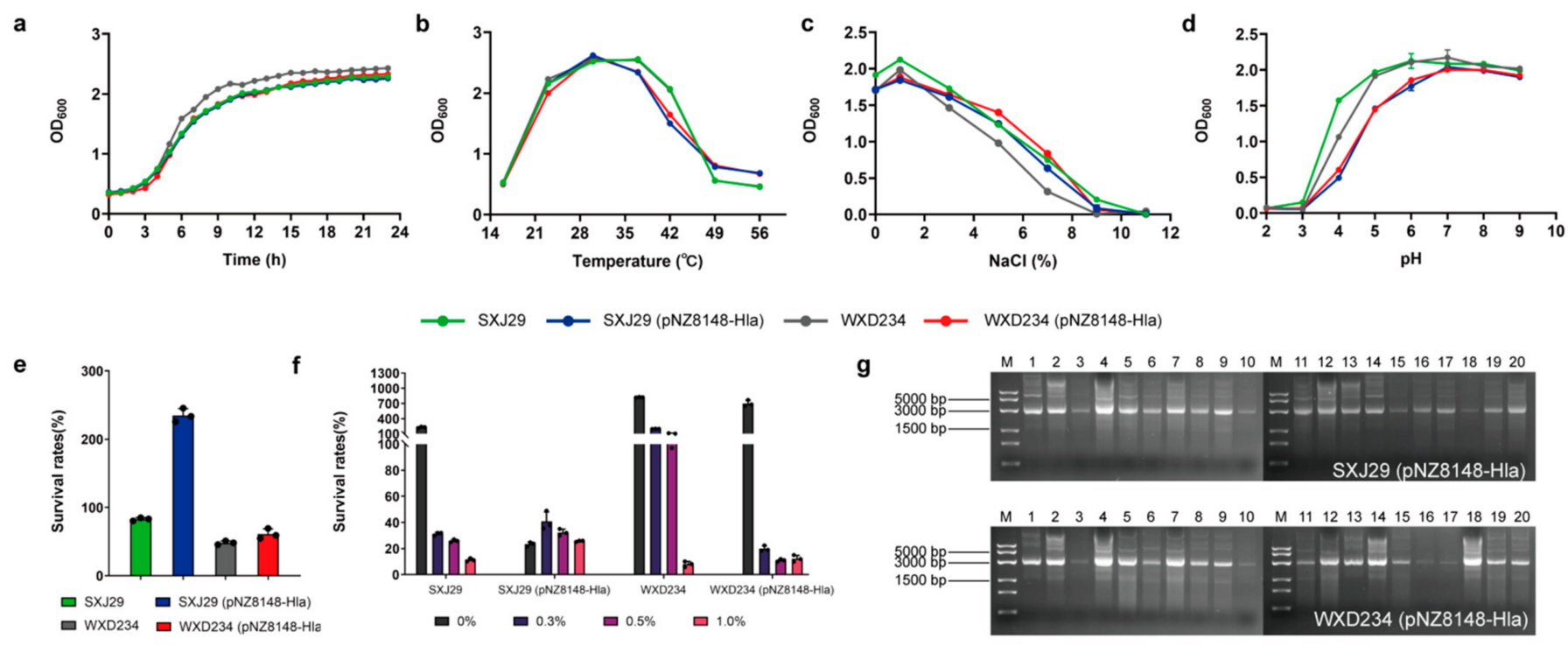

Figure 2. The physiological characteristics of recombinant Lactobacillus SXJ29 (pNZ8148-Hla), WXD234 (pNZ8148-Hla), and the wild strains SXJ29 and WXD234. (a) The growth curves of strains for $23 \mathrm{~h}$ were determined $(n=3)$. (b) Growth states of the strains under different temperatures $\left(16,23,30,37,42,49,56{ }^{\circ} \mathrm{C}\right)(n=3)$. (c) Growth states of the strains at different $\mathrm{pH}$ values $(2.0,3.0,4.0,5.0,6.0,7.0,8.0,9.0)(n=3)$. (d) Growth states of the strains at the different $\mathrm{NaCl}$ contents $(0 \%, 1 \%, 3 \%, 5 \%, 7 \%, 9 \%, 11 \%)(n=3)$. Data are shown as mean $\pm \mathrm{SD}$ for each group. (e) The acid tolerance of the strains was assessed in terms of viable colony counts after incubation with artificial gastric juice $(\mathrm{NaCl} 0.2 \%$ and pepsin $0.35 \%$ were dissolved in distilled water, and the $\mathrm{pH}$ was adjusted to 3.0, and filter sterilized with $0.22 \mu \mathrm{m}$ micro) at $37^{\circ} \mathrm{C}$ for $3 \mathrm{~h}$ ( $n=3$ ). (f) The bile tolerance of the strains was assessed in terms of viable colony counts after incubation with artificial bile salt intestinal juice (MRS broth with $0.68 \% \mathrm{KH}_{2} \mathrm{PO}_{4}$ and $1 \%$ trypsin, and the content of the bile salt was $0 \%, 0.3 \%, 0.5 \%$, and $1.0 \%)$ at $37^{\circ} \mathrm{C}$ for 0 and $24 \mathrm{~h}(n=3)$. (g) The plasmid pNZ8148-Hla have genetic stability in both SXJ29 (pNZ8148-Hla) and WXD234 (pNZ8148-Hla) and can stabilize the heredity for at least $20 \mathrm{~d}$.

\subsection{Recombinant Lactobacillus Colonize and Express Heterologous Protein Stably in the Intestine}

To monitor the colonization and persistence of recombinant Lactobacillus in vivo, recombinant Lactobacillus SXJ29 (pNZ8148-EGFP) and WXD234 (pNZ8148-EGFP) were constructed. EGFP can be stably expressed in recombinant Lactobacillus SXJ29 (pNZ8148EGFP) and WXD234 (pNZ8148-EGFP) in vitro by Western blotting and CLSM analysis (Figure 3a,e). 
a

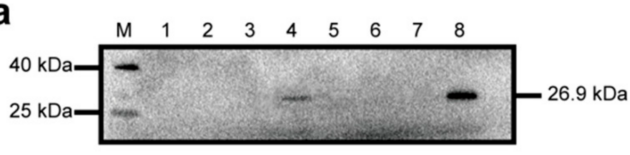

C

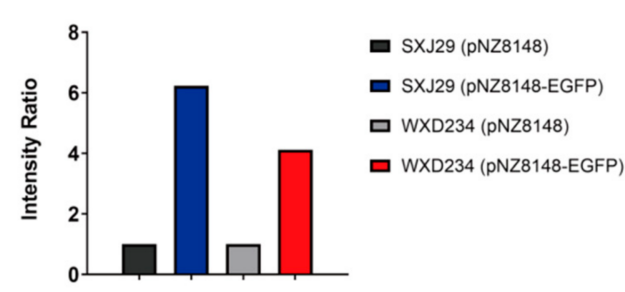

e
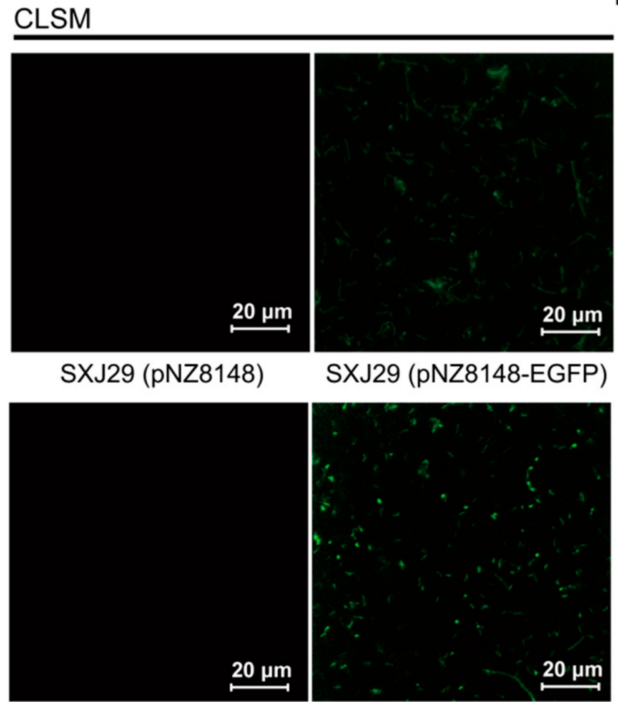

WXD234 (pNZ8148) WXD234 (pNZ8148-EGFP) b

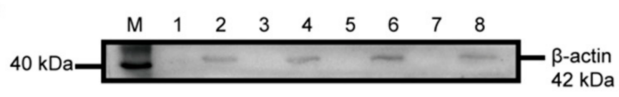

d

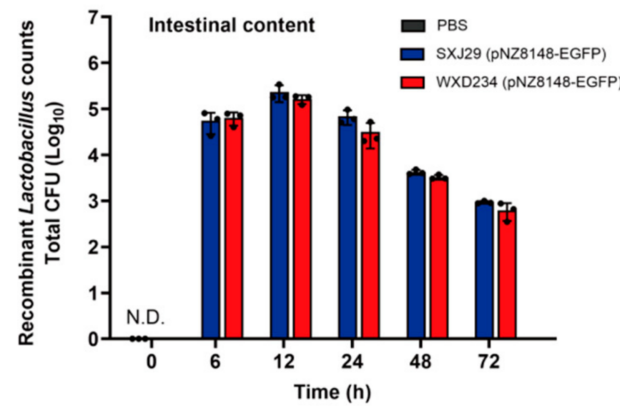

f

Fluorescence microscope analysis

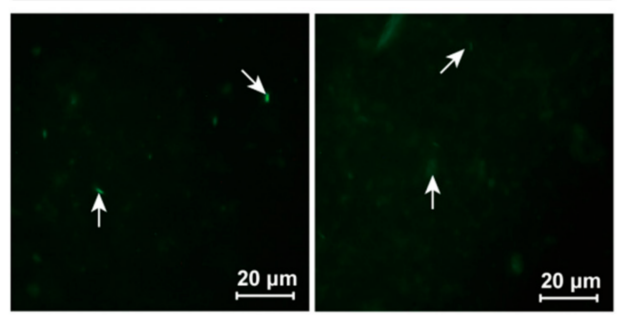

SXJ29 (pNZ8148-EGFP) WXD234 (pNZ8148-EGFP)

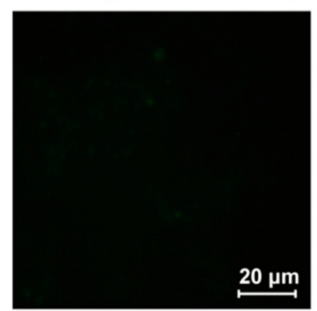

PBS

Figure 3. Recombinant Lactobacillus can persist for at least $72 \mathrm{~h}$ and can stably express heterologous protein in the intestine. Recombinant Lactobacillus SXJ29 (pNZ8148-EGFP) and WXD234 (pNZ8148-EGFP) were constructed, and EGFP expression on recombinant SXJ29/WXD234 (pNZ8148-EGFP) subjected to nisin induction was measured by Western blotting and CLSM. Culture supernatants and cell extracts were prepared and analyzed by Western blotting using anti-GFP mAb (a) or anti- $\beta$-actin $\mathrm{mAb}(\mathbf{b})$. Left: molecular masses of pre-stained marker proteins. Protein marker (Lane M). Culture supernatants of SXJ29 (pNZ8148) (Lane 1), SXJ29 (pNZ8148-EGFP) (Lane 3), WXD234 (pNZ8148) (Lane 5), WXD234 (pNZ8148-EGFP) (Lane 7); cell extracts of SXJ29 (pNZ8148) (Lane 2), SXJ (pNZ8148-EGFP) (Lane 4), WXD234 (pNZ8148) (Lane 6), and WXD234 (pNZ8148-EGFP) (Lane 8). (c) Intensity ratio of EGFP expression in SXJ29 and WXD234. (e) CLSM detection of EGFP expression on SXJ29/WXD234 (pNZ8148-EGFP). (d) Mice were orally administered SXJ29 (pNZ8148-EGFP), WXD234 (pNZ8148-EGFP) or PBS, and recombinant Lactobacillus colonization was monitored for $72 \mathrm{~h}(n=3)$. (f) Fluorescent detection of SXJ29/WXD234 (pNZ8148-EGFP) in the intestine $6 \mathrm{~h}$ after the oral administration of recombinant Lactobacillus under fluorescence microscopy.

The mouse experimental results showed that the geometric means of the total SXJ29/ WXD234 (pNZ8148-EGFP) CFUs in the intestinal contents were analyzed (Figure 3d) at $6,12,24,48$, and $72 \mathrm{~h}$ after the last intragastric administration with transformant. The data suggested that recombinant lactobacilli were able to colonize and persist, albeit at a reduced level, in the gastrointestinal tract, even at $72 \mathrm{~h}$ after post-administration. There was no significant difference in the amount of colonization between the SXJ29 (pNZ8148EGFP) and WXD234 (pNZ8148-EGFP) strains. Using fluorescence microscopy, it became apparent that fluorescent lactobacilli was contained in the intestinal contents of the mice $6 \mathrm{~h}$ post-administration (Figure 3f). These results indicate that recombinant Lactobacillus 
can persist in the intestine for at least $72 \mathrm{~h}$ and that heterologous protein can be stably expressed in the intestine.

\subsection{Recombinant Lactobacillus Elicited Intestinal Mucus IgA and Serum IgG-Mediated Immune Responses}

To examine the activation of humoral and mucosal immunity by recombinant SXJ29 (pNZ8148-Hla) and WXD234 (pNZ8148-Hla) from an antibody perspective, we measured serum IgG and intestinal mucus IgA levels. Hla $\mathrm{H}_{35 \mathrm{~L}}$-specific IgG was detected in sera from all of the vaccinated mice on days $0,7,14,21,28,35$, and 42 (Figure 4a). On days 28, 35, and 42 , levels differed significantly, and on day 35 , the levels were the highest. Levels of $\mathrm{Hla}_{\mathrm{H} 35 \mathrm{~L}}$-specific IgA that had been assayed in gastroenteric mucus showed a steady increase and peaked on day 42 in all of the vaccinated mice (Figure $4 \mathrm{~b}$ ). Taken together, these findings indicate that SXJ29 (pNZ8148-Hla) and WXD234 (pNZ8148-Hla) elicited IgG- and IgA-mediated immune responses.

a

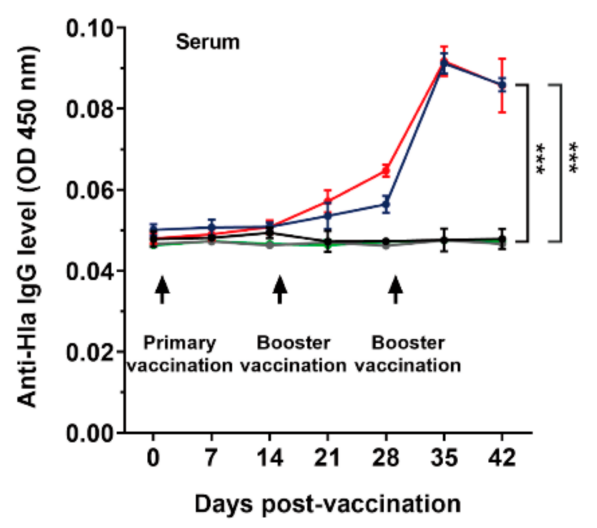

$\begin{aligned} \rightarrow \text { PBS } & \rightarrow \text { SXJ29 (pNZ8148) } \\ & \rightarrow \text { WXD234 (pNZ8148) }\end{aligned}$ b

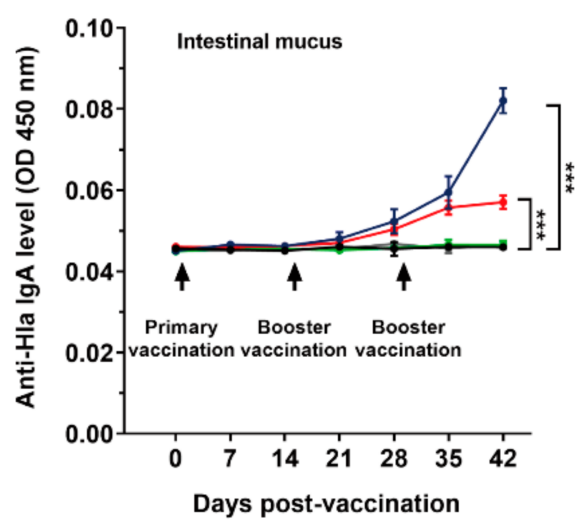

$\rightarrow$ SXJ29 (pNZ8148-Hla)

$\rightarrow$ WXD234 (pNZ8148-Hla)

Figure 4. Recombinant Lactobacillus elicited IgG- and IgA-mediated immune responses. Mice were vaccinated with SXJ29 (pNZ8148-Hla), WXD234 (pNZ8148-Hla), or PBS; samples were collected at 7-day intervals as indicated, and the IgG and IgA levels were measured. (a) Mean of Hla $\mathrm{H}_{35 \mathrm{~L}}$-specific IgG levels in serum $(n=3)$. (b) Mean of Hla $\mathrm{H}_{35 \mathrm{~L}}$-specific IgA levels in intestinal mucus $(n=3)$. Data are shown as mean $\pm \mathrm{SD}$ for each group. ${ }^{* * *} p<0.001$ for comparison with PBS group.

\subsection{Recombinant Lactobacillus Enhanced Lymphocyte Proliferation in Peyer's Patches}

T cell suspensions from the spleen and Peyer's patches were prepared from vaccinated mice on day 35 to further evaluate the effects of recombinant Lactobacillus SXJ29 (pNZ8148Hla) and WXD234 (pNZ8148-Hla) on cell-mediated immunity, and a MTS assay of the T-lymphocytes proliferation was performed. For both $\mathrm{Hla}_{\mathrm{H} 35 \mathrm{~L}}$ - and Con A-stimulated Peyer's patch lymphocytes, a significant enhancement in proliferation was observed for the WXD234 (pNZ8148-Hla) group, but feeble proliferation was observed for the SXJ29 (pNZ8148-Hla) group (Figure 5). The spleen T-lymphocytes showed no notable proliferation (data not shown). Thus, WXD234 (pNZ8148-Hla) apparently stimulated cell-mediated immune responses in the gut-associated lymphoid tissue (GALT). 


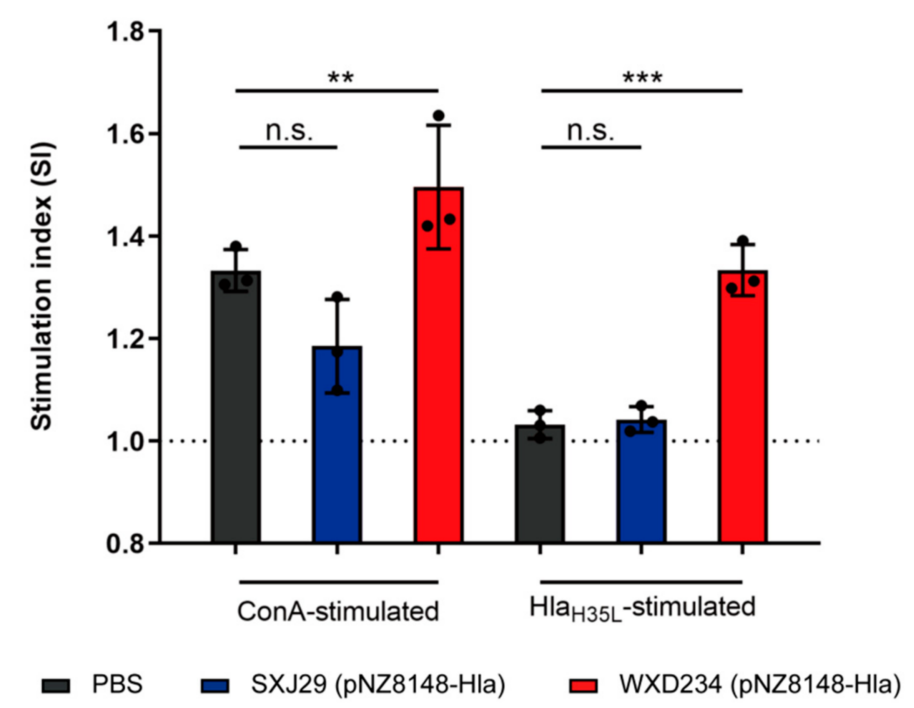

Figure 5. Recombinant Lactobacillus enhanced lymphocyte proliferation in Peyer's patches. Mice were vaccinated with SXJ29 (pNZ8148-Hla), WXD234 (pNZ8148-Hla), or PBS. On day 35, T-lymphocytes from Peyer's patches were prepared, restimulated with Hla $\mathrm{H}_{35 \mathrm{~L}}$ or Con A protein, and measured by MTS assay $(n=3)$. Results are shown as the stimulation index (SI). Data are shown as mean $\pm \mathrm{SD}$ for each group. ${ }^{* *} p<0.01 ;{ }^{* * *} p<0.001 ;$ n.s., not significant for comparison with PBS group.

\subsection{Recombinant Lactobacillus Enhanced Production of IL-2, IL-4, and IL-17 in Mesenteric Lymphatic Tissue}

T-helper (Th) cells mainly differentiate into Th1, Th2, and Th17 subsets [34] and play essential roles in promoting immune responses following bacterial infection or immunization [35-37]. Cytokines secreted by the T cells can be classified into Th1-related (IFN- $\gamma$, IL-2), Th2-related (IL-4, IL-10), and Th17-related (IL-17) cytokines [38,39]. We prepared a supernatant of the intestinal tissue homogenate in order to investigate the effects of our recombinant Lactobacillus on the production of IL-2, IL-4, IL-10, IL-17, and IFN- $\gamma$ by mesenteric lymphocytes. The IL-2, IL-4, and IL-17 levels were significantly higher in the WXD234 (pNZ8148-Hla)-vaccinated group than in the PBS group (Figure 6). The IL-2 and IL-4 levels were higher in the SXJ29 (pNZ8148-Hla)-vaccinated group than in the PBS group, but the difference was not significant. These findings indicate that WXD234 (pNZ8148-Hla) is capable of inducing Th1, Th2, and Th17 cell-mediated immune responses.
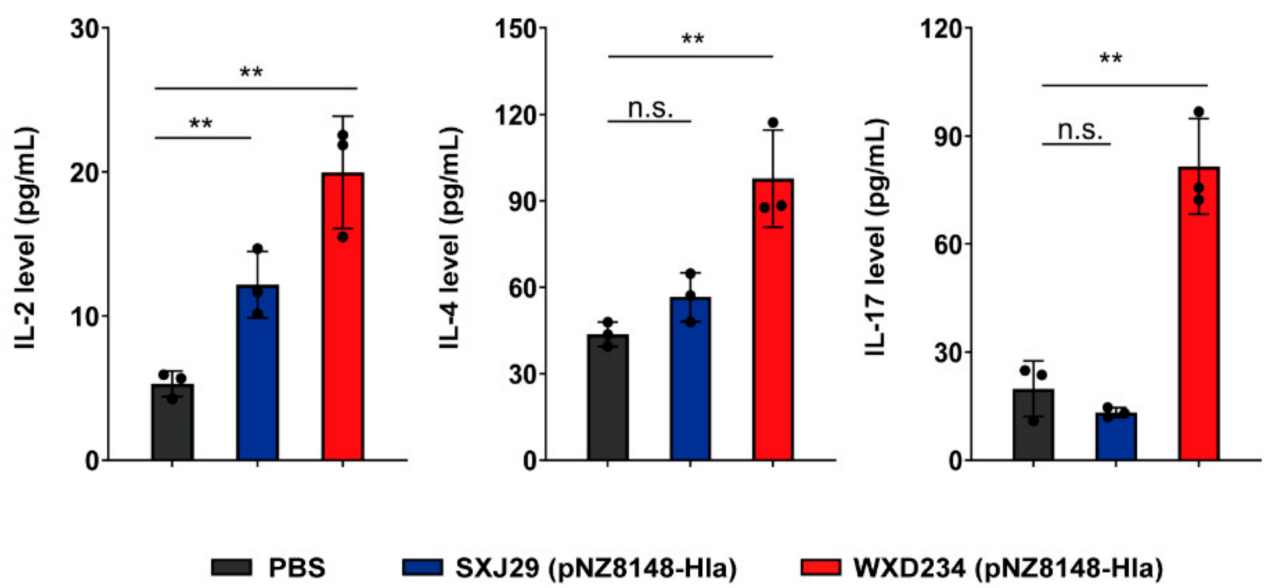

$\square$ WXD234 (pNZ8148-Hla)

Figure 6. WXD234 (pNZ8148-Hla) vaccination induced IL-2, IL-4 and IL-17 production of in mesenteric lymphatic tissue. Vaccinated mice were sacrificed on day 35, and the intestinal tissue was prepared. IL-2, IL-4, and IL-17 levels, determined by ELISA in a supernatant of intestinal tissue homogenate were analyzed $(n=3)$. Data are shown as mean $\pm \mathrm{SD}$ for each group. ${ }^{* *} p<0.01$; n.s., not significant for comparison with PBS group. 


\subsection{Recombinant Lactobacillus Effectively Protected Mice against S. aureus-Induced Pulmonary Infection}

To evaluate the effect of recombinant Lactobacillus on resistance to S. aureus infection, we constructed a $S$. aureus-induced pulmonary infection model. After intranasal challenging, survival rates were high for the WXD234 (pNZ8148-Hla) $(83 \% ; 10 / 12)$ and SXJ29 (pNZ8148-Hla) $(75 \%$; 9/12) groups but were much lower for the PBS $(8 \% ; 1 / 12)$, WXD234 (pNZ8148) $(33 \% ; 4 / 12)$, and SXJ29 (pNZ8148) $(25 \% ; 3 / 12)$ antigen-free groups (Figure $7 b)$. Moreover, the degree of $S$. aureus colonization in the lung was much lower for the SXJ29 (pNZ8148-Hla) and WXD234 (pNZ8148-Hla) groups than for the PBS group (Figure 7e). Meanwhile, the SXJ29 (pNZ8148-Hla)- or WXD234 (pNZ8148-Hla)-vaccinated mice only exhibited mild inflammatory reactions, whereas severe histopathological damage, including fragmentation of alveolar walls, infiltration of lymphocytes, and a large amount of erythrocyte exudation, were observed in PBS-treated mice (Figure 7c). Moreover, the lung histopathology scores (inflammation index), as defined by the percentage leukocyte infiltration cells, were significantly reduced in the SXJ29 (pNZ8148-Hla) and WXD234 (pNZ8148-Hla) groups compared to in the PBS group (Figure 7d). Although the antigenfree groups SXJ29 (pNZ8148) and WXD234 (pNZ8148) had a certain degree of protective ability, the recombinant bacteria containing $\mathrm{Hla}_{\mathrm{H} 35 \mathrm{~L}}$ could further improve the protective effect. Both the Lactobacillus vector and $\mathrm{Hla}_{\mathrm{H} 35 \mathrm{~L}}$ played important roles in this protective effect. These data therefore demonstrate the therapeutic effects of recombinant Lactobacillus in improving lung physiology and histopathology in vivo and support the potential use of SXJ29 (pNZ8148-Hla) and (particularly) WXD234 (pNZ8148-Hla) for protection against $S$. aureus-induced pulmonary infection.

\subsection{Recombinant Lactobacillus Promoted Resistance to S. aureus-Induced Skin Infection}

The skin, the body's largest mucosa organ, is home to a diverse and complex variety of innate and adaptive immune functions that protect against pathogenic invasion. To evaluate the effect of recombinant Lactobacillus WXD234 (pNZ8148-Hla) on resistance to S. aureus infection, we then constructed a S. aureus-induced skin infection model. Vaccinated mice were intradermally inoculated with $S$. aureus USA300 $\left(5 \times 10^{8} \mathrm{CFUs} / 50 \mu \mathrm{L} / \mathrm{mouse}\right)$ and developed visible skin lesions. The skin lesions of the WXD234 (pNZ8148-Hla)-vaccinated mice reached a maximal size of $4.32 \pm 0.13 \mathrm{~cm}^{2}$ by day 2 and healed by day 28 (Figure $8 \mathrm{a}, \mathrm{c}$ ). The non-vaccinated mice developed much larger lesions $\left(5.87 \pm 0.19 \mathrm{~cm}^{2}\right.$ by day 2$)$, which were still not completely healed by day 28 (Figure $8 \mathrm{a}, \mathrm{c}$ ). Histological evaluation (H\&E staining) of the skin at $24 \mathrm{~h}$ revealed large neutrophilic abscesses in the WXD234 (pNZ8148Hla)-vaccinated mice (Figure 8b). The numbers of $S$. aureus CFUs in the infection site at $24 \mathrm{~h}$ were $\sim 100$-fold higher in the non-vaccinated mice than in the WXD234 (pNZ8148-Hla)vaccinated mice (Figure 8d). Thus, recombinant Lactobacillus WXD234 (pNZ8148-Hla) promoted resistance to $S$. aureus-induced skin infection. 


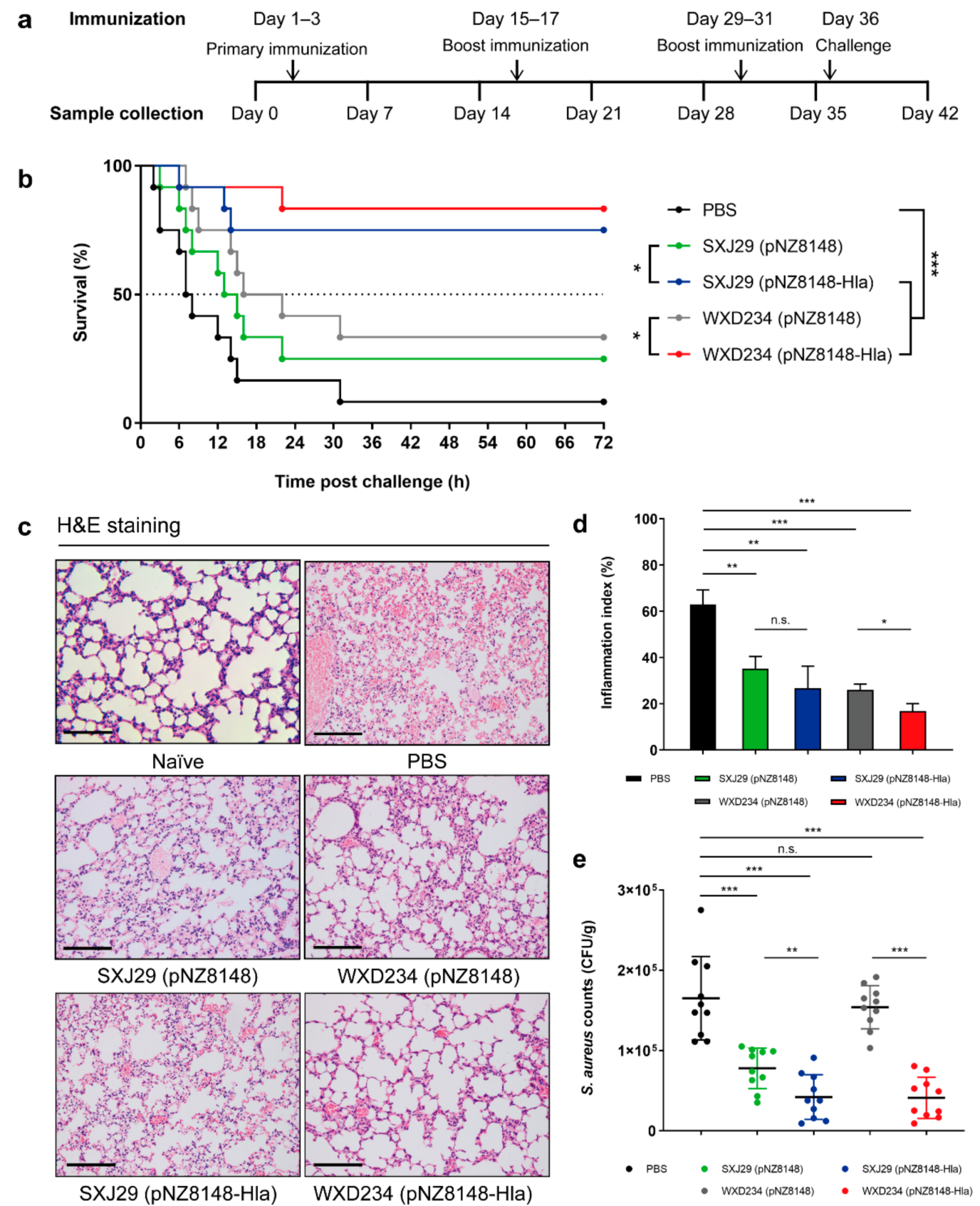

Figure 7. Recombinant Lactobacillus effectively improved the protection against S. aureus-induced pulmonary infection. (a) Immunization strategy and schedule for the collection of serum, feces, intestinal tissue, and intestinal mucus samples. (b) Vaccinated mice were inoculated with $40 \mu \mathrm{L}$ bacterial slurry $\left(5 \times 10^{9}\right.$ CFUs of S. aureus USA300) via the left nostril on day 36 and were held upright for $1 \mathrm{~min}$. Survival rates were monitored for $72 \mathrm{~h}(n=12)$. (c) Vaccinated mice were inoculated with $40 \mu \mathrm{L}$ bacterial slurry (lower dose: $5 \times 10^{8}$ CFUs of S. aureus USA300), as above. Histopathological evaluation of lung sections by light microscopy (H\&E staining; magnification $200 \times$; bar: $100 \mu \mathrm{m}$ ). (d) Inflammation index corresponding with histopathological evaluation $(n=10)$. (e) For the lower-dose $\left(5 \times 10^{8} \mathrm{CFUs}\right)$ group, the numbers of bacteria in lungs were counted $(n=10) .{ }^{*} p<0.05 ;{ }^{* *} p<0.01 ;{ }^{* * *} p<0.001 ;$ n.s., not significant. 
a

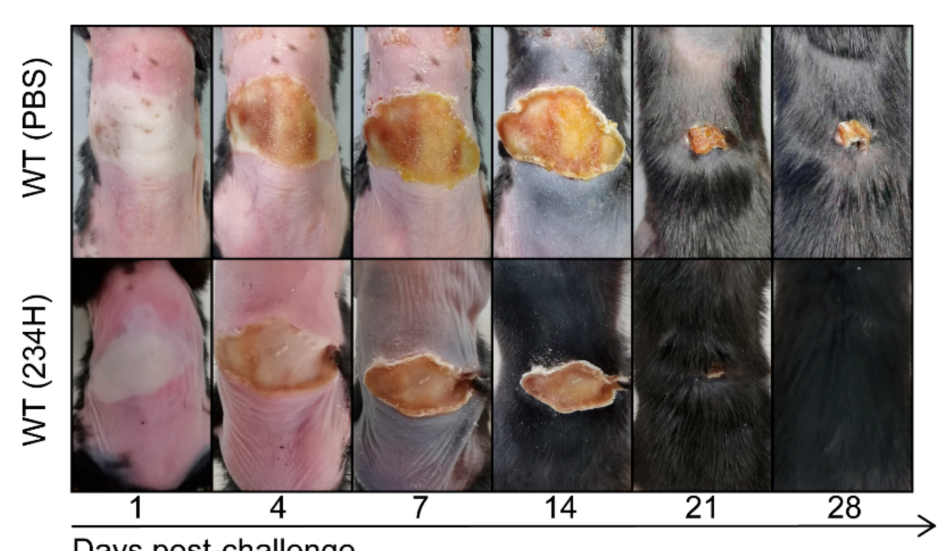

Days post-challenge

C

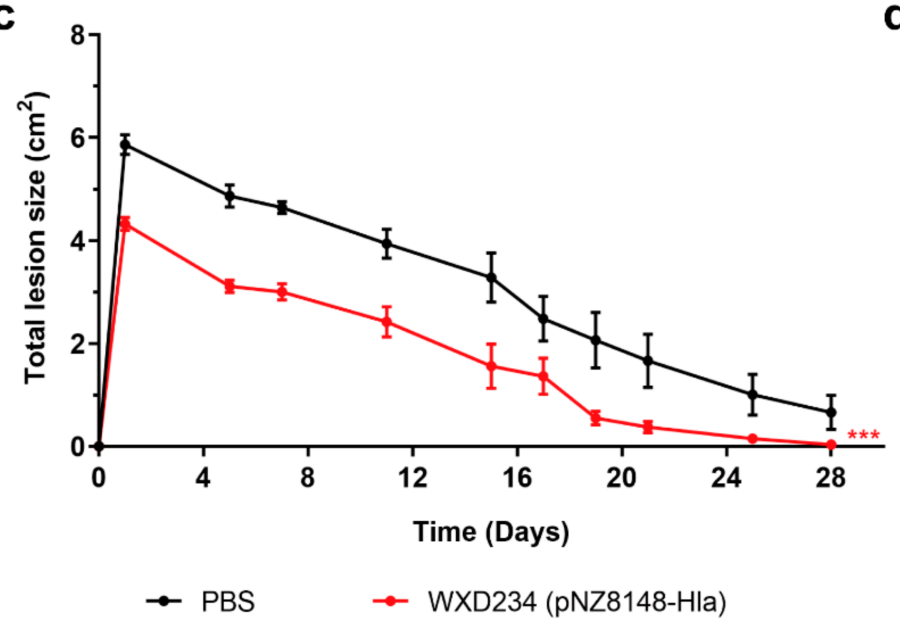

b

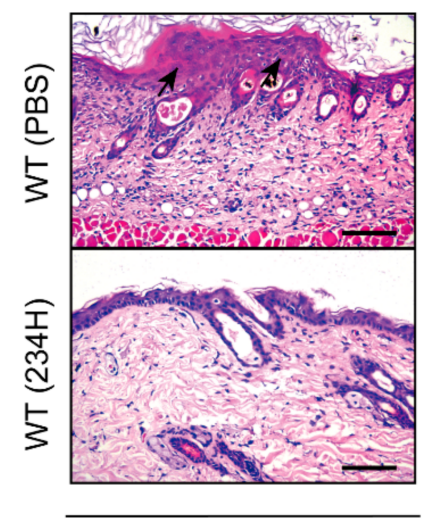

H\&E staining

d

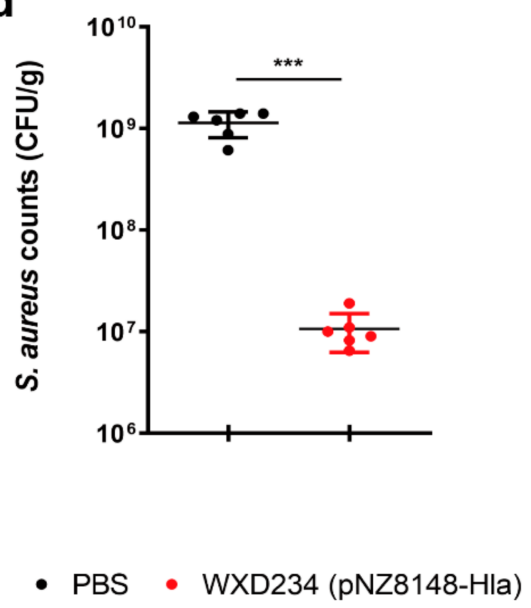

Figure 8. Recombinant Lactobacillus WXD234 (pNZ8148-Hla) promoted resistance to S. aureus-induced skin infection. (a) WT C57BL/ 6 mice were vaccinated with WXD234 (pNZ8148-Hla) or PBS and then challenged with S. aureus USA300 by the dorsal s.c. injection of $5 \times 10^{8} \mathrm{CFUs} / 50 \mu \mathrm{L} /$ mouse on day 36, and the lesion sizes were monitored for 28 days $(n=6)$. Representative photographs of skin lesions are shown. (c) Total lesion sizes $\left(\mathrm{cm}^{2}\right) \pm \operatorname{SEM}(n=6)$ are shown. ${ }^{* * *} p<0.001$ for comparison with the PBS group. (b) Histopathological evaluation of skin infection (H \& E staining; magnification $200 \times$; bar: $200 \mu \mathrm{m} ; n=3)$. (d) Number of bacteria in lesions were counted $(n=3)$ at $24 \mathrm{~h}$ post infection. Data are shown as mean $\pm \mathrm{SD}$ for each group. ${ }^{* *} p<0.001$ for comparison with PBS group.

3.8. Recombinant Lactobacillus Lost Superior Protection Post Vaccination in TCR $\gamma / \delta$-Deficient or IL-17A-Deficient Mice

$\gamma \delta \mathrm{T}$ cells are an important subset of "unconventional" T-lymphocytes that are present in epithelial tissues, including in the gastrointestinal tract, skin epidermis, and reproductive tract [40]. $\gamma \delta$ T cells function as a bridge between innate and adaptive immune responses and therefore have essential roles in mucosal immunity [41]. $\gamma \delta \mathrm{T}$ cells evidently play a key role in the immune response to $S$. aureus skin infections [42]. The contribution of $\gamma \delta$ $\mathrm{T}$ cells to $S$. aureus-induced pulmonary and skin infection was evaluated by vaccinating the WT and TCR $\gamma / \delta$-deficient mice with WXD234 (pNZ8148-Hla) in our model system. A murine model of a pulmonary infection model was established, and survival rates were calculated on day 36 . The survival rate was significantly higher for the WT $(234 \mathrm{H})$ group $(80 \% ; 8 / 10)$ than for the WT (PBS) group $(20 \% ; 2 / 10)$ or the TCR $\gamma / \delta^{-/-}(234 \mathrm{H})$ group $(50 \% ; 5 / 10)$ (Figure 9 a). The histological evaluation of these groups in our S. aureusinduced pulmonary infection model was based on H\&E staining and a light microscopic examination of the lung sections. The WT $(234 \mathrm{H})$ group had clear alveolar airspaces, continuous thin alveolar walls and capillary vessels, clearly delineated extra-alveolar 
vessels with no evident patent lymphatics in adventitia, and a small number of neutrophils, which were confined to the septal network (Figure 9b). In contrast, the WT (PBS) and TCR $\gamma / \delta^{-1-}(234 \mathrm{H})$ groups displayed interstitial edema, neutrophil infiltration, and thickened alveolar walls. Meanwhile, the contribution of $\gamma \delta \mathrm{T}$ cells to S. aureus-induced skin infection was evaluated by vaccinating WT and TCR $\gamma / \delta$-deficient mice with WXD234 (pNZ8148Hla) and by measuring the lesion size in our model system. The WXD234 (pNZ8148-Hla)vaccinated mice developed lower skin lesions. In contrast, vaccinated TCR $\gamma / \delta^{-/-}$mice developed lesions that were $\sim 1.5$ to 2 -fold larger and that did not heal completely by day 21; however, this is still lower than for the non-vaccinated mice (Figure 9c,d). Taken together, these results indicate that recombinant Lactobacillus WXD234 (pNZ8148-Hla) lost superior protection post vaccination in the TCR $\gamma / \delta$-deficient mice in both the $S$. aureus-induced pulmonary infection and skin infection groups.

a

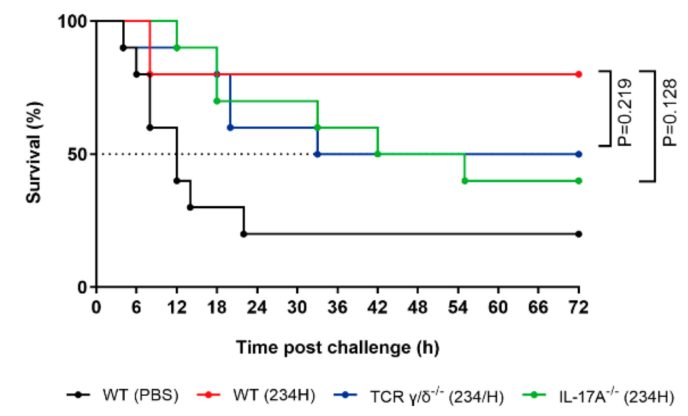

c

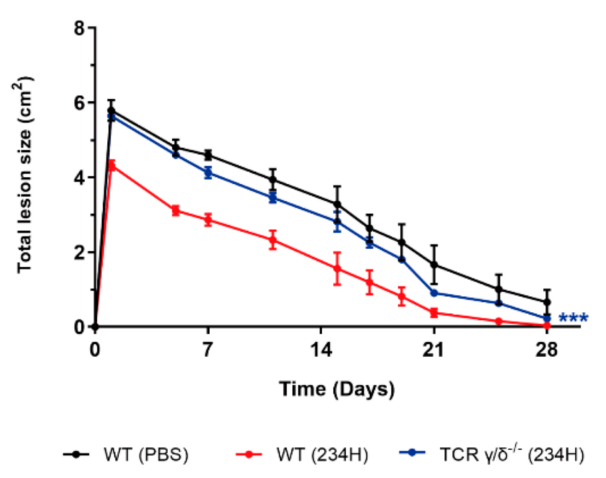

b H\&E staining

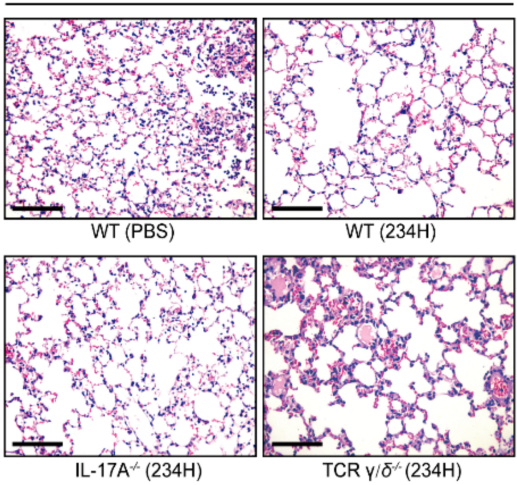

d

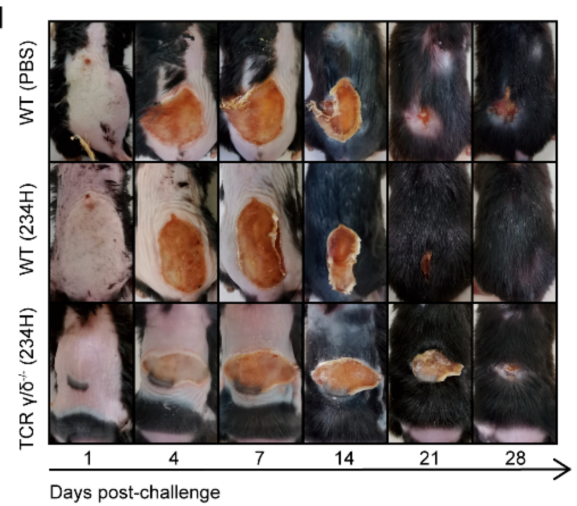

Figure 9. Protection offered by WXD234 (pNZ8148-Hla) vaccination decreased when $\gamma \delta \mathrm{T}$ cell or IL-17 absent. (a) WT, IL-17A ${ }^{-/-}$, and TCR $\gamma / \delta^{-/-}$C57BL/ 6 mice vaccinated with WXD234 (pNZ8148-Hla) were inoculated with $60 \mu \mathrm{L}$ bacterial slurry $\left(2.2 \times 10^{10}\right.$ CFUs S. aureus USA300), as described above. Survival rates were monitored for $72 \mathrm{~h}(n=10)$. (b) Vaccinated mice were inoculated with $50 \mu \mathrm{L}$ bacterial slurry (lower dose: $5 \times 10^{8}$ CFUs of $S$. aureus USA300), as described above. Histopathological evaluation of lung sections by light microscopy (H \& E staining; magnification $200 \times$; bar: $100 \mu \mathrm{m})$. (c) Total lesion size $\left(\mathrm{cm}^{2}\right) \pm \operatorname{SEM}(n=6)$ are shown. ${ }^{* * *} p<0.001$ for comparison between TCR $\gamma / \delta^{-/-}(234 \mathrm{H})$ and WT $(234 \mathrm{H})$ groups. (d) WT and TCR $\gamma / \delta^{-/-}$C57BL/6 mice vaccinated with WXD234 (pNZ8148-Hla) were challenged with S. aureus USA300 by dorsal s.c. injection of $5 \times 10^{8} \mathrm{CFUs} / 50 \mu \mathrm{L} /$ mouse on day 36 , and lesion sizes were monitored for 28 days $(n=6)$. Representative photographs of skin lesions are shown.

The increased IL-17 level produced by WXD234 (pNZ8148-Hla) vaccination was of particular interest. IL-17 plays a key role in host defense against S. aureus infection, and immunomodulatory therapies or vaccines that enhance IL-17 response have strong potential in this regard [43]. We investigated roles of IL-17 by evaluating the protective effect of WXD234 (pNZ8148-Hla) in WT and IL-17A ${ }^{-/-}$C57BL/6 mice. Survival rates were 
significantly lower for the IL-17A ${ }^{-/-}(234 \mathrm{H})$ group $(40 \% ; 4 / 10)$ than for the WT $(234 \mathrm{H})$ group $(80 \% ; 8 / 10)$ (Figure $9 a)$. The histological evaluation of IL-17A ${ }^{-/-}(234 \mathrm{H})$ group displayed significant histopathological damage (Figure $9 \mathrm{~b}$ ). These findings indicate that WXD234 (pNZ8148-Hla) provided effective protection against S. aureus-induced pulmonary infection, and this protection decreased when IL-17 was absent.

Table 1. Bacterial strains and plasmids used in this study.

\begin{tabular}{|c|c|c|}
\hline Strain or Plasmid & Description & Source or Reference \\
\hline \multicolumn{3}{|l|}{ Strains } \\
\hline SXJ29 & WT Lactobacillus kefiri & Isolated from dairy products \\
\hline WXD234 & WT Lactobacillus plantarum & Isolated from dairy products \\
\hline SXJ29 (pNZ8148) & Derivative of SXJ29 carrying pNZ8148 & This study \\
\hline WXD234 (pNZ8148) & Derivative of WXD234 carrying pNZ8148 & This study \\
\hline SXJ29 (pNZ8148-Hla) & Derivative of SXJ29 carrying pNZ8148-Hla & This study \\
\hline WXD234 (pNZ8148-Hla) & Derivative of WXD234 carrying pNZ8148-Hla & This study \\
\hline SXJ29 (pNZ8148-EGFP) & Derivative of SXJ29 carrying pNZ8148-EGFP & This study \\
\hline WXD234 (pNZ8148-EGFP) & Derivative of WXD234 carrying pNZ8148-EGFP & This study \\
\hline S. aureus USA300 & S. aureus USA300 & $\begin{array}{l}\text { American Type Culture Collection } \\
\text { (Manassas, VA, USA) }\end{array}$ \\
\hline \multicolumn{3}{|l|}{ Plasmids } \\
\hline pUC57-Hla & Amp $^{\mathrm{r}}$; pUC57::spslpA::his-tag::hla ${ }_{H 35 L}$ & GenScript Bio Co. \\
\hline pNZ8148 & $\mathrm{Cm}^{\mathrm{r}} ;$ L. lactis expression vector; $\mathrm{P}_{\text {nisA }}$ promoter & Nanjing ZFdows Bio Co. [44] \\
\hline pNZ8148-Hla & $\mathrm{Cm}^{\mathrm{r}} ; \mathrm{pNZ} 8148:: \mathrm{SP} s l p A::$ his-tag::hla ${ }_{\mathrm{H} 35 \mathrm{~L}}$ & This study \\
\hline pNZ8148-EGFP & $\mathrm{Cm}^{\mathrm{r}} ;$ pNZ8148::egfp & This study \\
\hline
\end{tabular}

\section{Discussion}

Numerous scientific institutions and research groups have attempted to develop effective vaccines against $S$. aureus during the past two decades, but so far, these attempts have had limited success [6]. Such attempts face major challenges that have been discussed extensively in several review articles [6,7]. At present, research based on Lactococcus accounts for the majority of the research that has been conducted in the development of a lactic acid bacteria (LAB) delivery system because Lactococcus was the first species of LAB to have its genome fully sequenced, which has allowed a better understanding of its physiological mechanisms and gene editing manipulation [45-48]. In recent years, lactobacilli, which have low innate immunogenicity and low modulating non-specific immunity, have been widely used to develop oral vaccines as delivery vehicles [49-51]. However, the possible use of lactobacilli as a delivery system for a $S$. aureus vaccine has not been investigated. For this purpose, we designed oral vaccines based on L. kefiri SXJ29 and L. plantarum WXD234, taking advantage of their adaptability to the gastrointestinal environment and their probiotic properties. Recombinant Lactobacillus WXD234 (pNZ8148Hla) provides superior immunoprotective effects in mouse models of S. aureus-induced pulmonary and skin infections.

When $S$. aureus initially colonizes an infection site, it affects the host immune system by producing virulence factors [52]. $\alpha$-hemolysins (Hla) plays key roles in the pathogenesis of $S$. aureus-induced infections, which kill many types of cells through formation of heptameric membrane pores $[53,54]$. We created Hla mutants to minimize toxic effects. Previous studies have shown that active immunization with non-toxic mutant $\alpha$-hemolysins $\left(\mathrm{Hla}_{\mathrm{H} 35 \mathrm{~L}}\right)$ that are unable to form pores or passive immunization with $\mathrm{Hla}_{\mathrm{H} 35 \mathrm{~L}}$-specific antisera improve the protection against $S$. aureus-induced pulmonary and skin infections $[55,56]$. Lactobacilli vehicles have strong potential as vaccine vectors because of their ability to function as both adjuvants and vectors, enhancing the effect of the exogenous antigen on the systemic immune system [57]. We selected $\mathrm{Hla}_{\mathrm{H} 35 \mathrm{~L}}$ as an antigen and SXJ29 and WXD234 as recipient bacteria for the construction of an anti-S. aureus oral vaccine. The surface displayed proteins in L. lactis were considered more stable and had a higher bioactivity than their secreted counterparts $[58,59]$. Therefore, Hla $\mathrm{H}_{35 \mathrm{~L}}$ was linked to a $90-\mathrm{bp}$ fragment encoding a L. brevis 
S-layer signal peptide, thus inducing more efficient secretion and transportation of the target protein to the cell surface to facilitate $\mathrm{Hla}_{\mathrm{H} 35 \mathrm{~L}}$ function $[29,60]$.

The balance or ratio of Th1, Th2, and Th17 cells is important for a healthy immune response [61]. IFN- $\gamma$ produced by $\mathrm{CD} 8^{+} \mathrm{T}$ cells and certain $\mathrm{CD} 4^{+} \mathrm{T}$ cells (especially Th1 cells) can enhance the activity of Th1 cells and can promote cellular immune function [62]. The Th2-type immune response is marked by the secretion of cytokine IL-4 and the induction of specific antibodies [63]; the Th17-type is marked by IL-17 and IgA [64]. Oral vaccination has been shown to elicit mucosal immune responses; in particular, effective intestinal mucosal immune response requires the production of both mucosal secretory $\operatorname{IgA}(\operatorname{sg} \mathrm{A}$ ) and serum IgG antibodies to inhibit colonization by pathogens and their further spread to systemic circulation [65,66]. Recombinant Lactobacillus WXD234 (pNZ8148-Hla) apparently induces robust mucosal immunity in the GALT, as evidenced by a significant increase in IgA (Figure 4a) and IL-17 (Figure 6) production and the strong proliferation of the T-lymphocytes derived from Peyer's patches (Figure 5). However, WXD234 (pNZ8148-Hla) could not stimulate a systemic immune response effectively because of the feeble proliferation of the T-lymphocytes derived from the spleen (data not shown) and the low level of IgG (Figure 4a). Nevertheless, the recombinant Lactobacillus showed a high protective effect in subsequent mouse models of $S$. aureus-induced pulmonary and skin infection, which was attributed to a strong mucosal immune response.

The use of an animal model reflecting the characteristics of clinical S. aureus infection is an essential evaluation method for the preclinical studies of vaccine. The mouse pulmonary infection model was established to simulate the infection pathways of S. aureus and was used for the evaluation of the immunogenicity and the immunoprotective effect of the $S$. aureus oral vaccines. This provided considerable experimental reference for the development of a $S$. aureus vaccine. As a result, data on survival rates, bacterial colonization, and pathological analysis in the pulmonary infection model (Figure 7) clearly indicate stronger resistance to infection in the vaccinated groups relative to the antigen-free and PBS groups, e.g., the survival rate was $83 \%$ for the WXD234 group vs. $8 \%$ for the PBS group. However, antigen-free Lactobacillus still have a degree protection, which proved that both lactobacilli and Hla $\mathrm{H}_{35 \mathrm{~L}}$ play important roles in this protective effect. It is a remarkable fact that the oral vaccine based on L. plantarum WXD234 is better than that based on L. kefiri SXJ29 in terms of survival rate, pulmonary inflammation, or bacteria burden. Both the vehicle bacteria and the antigen contribute to the protective efficacy provided by a bacterial vaccine. As adjuvants, Lactobacillus influence innate immune cells such as macrophage or DCs, which, in turn, promote antigen presentation and the production of protective antigen specific antibodies in response to vaccination [67]. Different species of Lactobacillus, even different strains, show diverse adjuvant properties against bacterial or viral infection. The major immunological benefit of lactobacilli is the modulation of the host immune responses via interacting with the GI mucosa [68]. Different Lactobacillus strains may activate different components of the immune response due to specific capacities to produce particular surface molecules and the secretion of various proteins and metabolites that influence the host cells [69-71]. In previous studies, we found that compared toSXJ29, depending on the full advantage of their own probiotic features, WXD234 has a good immunoprotective effect in mouse models of $S$. aureus-induced pulmonary infection. The superior protection of WXD234 (pNZ8148-Hla) may be related to its induction of higher levels of IL-17 production. The WXD234 mechanism exerts a superior immunomodulatory effect that is not precisely known; however, we still need further studies. In addition, the difference in the immunoprotective effects between the two strains may be caused by the different expression levels of the antigen, and expression levels of antigen need quantification. The skin, the body's largest mucosa organ, is home to a diverse and complex variety of innate and adaptive immune functions that protect against pathogenic invasion. We evaluated the protective effect of WXD234 (pNZ8148-Hla), which has shown great immune protection in the above findings in a mouse model of a S. aureus-induced skin infection. WXD234 
(pNZ8148-Hla) could significantly reduce the abscess size in the S. aureus skin infection model.

The levels of Th1-type (IL-2), Th2-type (IL-4), and Th17-type (IL-17) cytokines in the mesenteric lymphatic tissue were significantly higher for the WXD234-vaccinated group than for the PBS group (Figure 7), indicating the strong induction of the Th1-, Th2-, and Th17-cell responses by WXD234. There has been some controversy regarding the immunoprotective properties of $S$. aureus vaccines. Currently, the general consensus is that cell-mediated immunity (Th1/Th17) and neutrophil activation are essential for effective immunoprotection, while antibodies play supporting roles in the opsonization and/or neutralization of virulence factors [72-74]. Increased levels of cytokine IL-17 in the WXD234 group appears to be a crucial step in the potentiation of a mucosal immune response against foreign antigens. IL-17 is predominantly produced by Th17 cells [75] and plays a key role in a variety of immune and inflammatory responses by regulating the expression of inflammatory mediators such as other cytokines, chemokines, and adhesion molecules [76-78]. $\gamma \delta \mathrm{T}$ cells provide a link between innate and adaptive immunity and are mainly distributed in skin and mucosal tissues [78]. We conducted a preliminary investigation on the role of IL-17 and $\gamma \delta$ T cells in the protective effect of WXD234 in WT, IL-17A ${ }^{-/-}$, and TCR $\gamma / \delta^{-/-}$C57BL $/ 6$ mice. Of particular interest is the sharp reduction of are protective effect offered by WXD234 (pNZ8148-Hla) when $\gamma \delta$ T cells or cytokine IL-17 are absent. Thus, $\gamma \delta$ T cells or IL-17 may be involved in the protective effect of WXD234 (pNZ8148-Hla) against S. aureus-induced pulmonary or skin infections.

In summary, the genetically engineered S. aureus oral vaccines SXJ29 (pNZ8148-Hla) and WXD234 (pNZ8148-Hla) constructed in this study effectively induced immune responses and improved protection against $S$. aureus-induced pulmonary infection in mouse models. Moreover, WXD234 (pNZ8148-Hla) in particular significantly reduced the abscess size in the $S$. aureus skin infection model and is a promising candidate for future clinical application.

\section{Conclusions}

The oral delivery of novel recombinant Lactobacillus elicits high protection against S. aureus pulmonary and skin infections. Our findings provide a great potential for a delivery system based on lactobacilli and provide experimental data for the development of $S$. aureus mucosal vaccines.

Author Contributions: Investigation, H.P. and S.S.; methodology, B.L., X.B. and H.Z.; software, Y.L.; writing-review and editing, X.W. and N.P.; project administration, X.W. All authors have read and agreed to the published version of the manuscript.

Funding: This work was supported by the National Natural Science Foundation of China (grant numbers 32060800 and 31660706). This study is supported by the Science and Technology Major Project of the Inner Mongolia Autonomous Region of China to the State Key Laboratory of Reproductive Regulation and Breeding of Grassland Livestock (grant numbers 2019ZD031 and zdzx2018065).

Institutional Review Board Statement: The study was conducted according to the guidelines of the Declaration of Helsinki. All animal related experimental protocols applied in this study were conducted under the standards of Ethics Committee of Inner Mongolia Medical University (SCXK2016-0001).

Informed Consent Statement: Not applicable.

Data Availability Statement: All data that this study is based upon are available from the corresponding author upon request.

Acknowledgments: The authors are grateful to Zhinan Yin for providing the IL-17A ${ }^{-/-}$and TCR $\gamma / \delta^{-/-}$mice and to S. Anderson for the English editing of the manuscript.

Conflicts of Interest: The authors declare no conflict of interest. The funders had no role in the design of the study; in the collection, analyses, or interpretation of data; in the writing of the manuscript; or in the decision to publish the results. 


\section{References}

1. Byrd, A.L.; Belkaid, Y.; Segre, J.A. The human skin microbiome. Nat. Rev. Microbiol. 2018, 16, 143-155. [CrossRef]

2. Tacconelli, E.; Carrara, E.; Savoldi, A.; Harbarth, S.; Mendelson, M.; Monnet, D.L.; Pulcini, C.; Kahlmeter, G.; Kluytmans, J.; Carmeli, Y.; et al. Discovery, research, and development of new antibiotics: The WHO priority list of antibiotic-resistant bacteria and tuberculosis. Lancet Infect. Dis. 2018, 18, 318-327. [CrossRef]

3. Lee, A.S.; de Lencastre, H.; Garau, J.; Kluytmans, J.; Malhotra-Kumar, S.; Peschel, A.; Harbarth, S. Methicillin-resistant Staphylococcus aureus. Nat. Rev. Dis. Primers 2018, 4, 18033. [CrossRef]

4. Tong, S.Y.; Davis, J.S.; Eichenberger, E.; Holland, T.L.; Fowler, V.G., Jr. Staphylococcus aureus infections: Epidemiology, pathophysiology, clinical manifestations, and management. Clin. Microbiol. Rev. 2015, 28, 603-661. [CrossRef]

5. $\quad$ Lucero, C.A.; Hageman, J.; Zell, E.R.; Bulens, S.; Nadle, J.; Petit, S.; Gershman, K.; Ray, S.; Harrison, L.H.; Lynfield, R.; et al. Evaluating the potential public health impact of a Staphylococcus aureus vaccine through use of population-based surveillance for invasive methicillin-resistant S. aureus disease in the United States. Vaccine 2009, 27, 5061-5068. [CrossRef] [PubMed]

6. Ansari, S.; Jha, R.K.; Mishra, S.K.; Tiwari, B.R.; Asaad, A.M. Recent advances in Staphylococcus aureus infection: Focus on vaccine development. Infect. Drug Resist. 2019, 12, 1243-1255. [CrossRef]

7. O'Brien, E.C.; McLoughlin, R.M. Considering the 'alternatives' for next-generation anti-Staphylococcus aureus vaccine development. Trends Mol. Med. 2019, 25, 171-184. [CrossRef] [PubMed]

8. Miller, L.S.; Fowler, V.G.; Shukla, S.K.; Rose, W.E.; Proctor, R.A. Development of a vaccine against Staphylococcus aureus invasive infections: Evidence based on human immunity, genetics and bacterial evasion mechanisms. FEMS Microbiol. Rev. 2020, 44, 123-153. [CrossRef] [PubMed]

9. Chumakov, K.; Ehrenfeld, E.; Wimmer, E.; Agol, V.I. Vaccination against polio should not be stopped. Nat. Rev. Microbiol. 2007, 5, 952-958. [CrossRef] [PubMed]

10. Longini, I.M., Jr.; Nizam, A.; Ali, M.; Yunus, M.; Shenvi, N.; Clemens, J.D. Controlling endemic cholera with oral vaccines. PLoS Med. 2007, 4, e336. [CrossRef]

11. Avtushenko, S.S.; Sorokin, E.M.; Zoschenkova, N.Y.; Zacharova, N.G.; Naichin, A.N. Clinical and immunological characteristics of the emulsion form of inactivated influenza vaccine delivered by oral immunization. J. Biotechnol. 1996, 44, 21-28. [CrossRef]

12. Lazzell, V.; Waldman, R.H.; Rose, C.; Khakoo, R.; Jacknowitz, A.; Howard, S. Immunization against influenza in humans using an oral enteric-coated killed virus vaccine. J. Biol. Stand. 1984, 12, 315-321. [CrossRef]

13. Seo, S.U.; Kim, J.J.; Yang, H.; Kwon, H.J.; Yang, J.Y.; Curtiss Iii, R.; Kweon, M.N. Effective protection against secondary pneumococcal pneumonia by oral vaccination with attenuated Salmonella delivering PspA antigen in mice. Vaccine 2012, 30, 6816-6823. [CrossRef]

14. García, V.E.; Iglesias, M.F.; Cerquetti, M.C.; Gómez, M.I.; Sordelli, D.O. Interaction between granulocytes and antibodies in the enhancement of lung defenses against Staphylococcus aureus after intranasal immunization of mice with live-attenuated bacteria. FEMS Immunol. Med. Microbiol. 1994, 9, 55-63. [CrossRef]

15. Narita, K.; Hu, D.L.; Tsuji, T.; Nakane, A. Intranasal immunization of mutant toxic shock syndrome toxin 1 elicits systemic and mucosal immune response against Staphylococcus aureus infection. FEMS Immunol. Med. Microbiol. 2008, 52, 389-396. [CrossRef] [PubMed]

16. Castagliuolo, I.; Piccinini, R.; Beggiao, E.; Palù, G.; Mengoli, C.; Ditadi, F.; Vicenzoni, G.; Zecconi, A. Mucosal genetic immunization against four adhesins protects against Staphylococcus aureus-induced mastitis in mice. Vaccine 2006, 24, 4393-4402. [CrossRef] [PubMed]

17. Sun, H.; Wei, C.; Liu, B.; Jing, H.; Feng, Q.; Tong, Y.; Yang, Y.; Yang, L.; Zuo, Q.; Zhang, Y.; et al. Induction of systemic and mucosal immunity against methicillin-resistant Staphylococcus aureus infection by a novel nanoemulsion adjuvant vaccine. Int. J. Nanomed. 2015, 10, 7275-7290. [CrossRef]

18. Irene, C.; Fantappiè, L.; Caproni, E.; Zerbini, F.; Anesi, A.; Tomasi, M.; Zanella, I.; Stupia, S.; Prete, S.; Valensin, S.; et al. Bacterial outer membrane vesicles engineered with lipidated antigens as a platform for Staphylococcus aureus vaccine. Proc. Natl. Acad. Sci. USA 2019, 116, 21780-21788. [CrossRef]

19. Guglielmotti, D.M.; Marcó, M.; Golowczyc, M.; Reinheimer, J.A.; Quiberoni, A. Probiotic potential of Lactobacillus delbrueckii strains and their phage resistant mutants. Int. Dairy J. 2007, 17, 916-925. [CrossRef]

20. Oliveira, M.L.; Arêas, A.P.; Campos, I.B.; Monedero, V.; Perez-Martínez, G.; Miyaji, E.N.; Leite, L.C.; Aires, K.A.; Lee Ho, P. Induction of systemic and mucosal immune response and decrease in Streptococcus pneumoniae colonization by nasal inoculation of mice with recombinant lactic acid bacteria expressing pneumococcal surface antigen A. Microbes Infect. 2006, 8, 1016-1024. [CrossRef]

21. Ho, P.S.; Kwang, J.; Lee, Y.K. Intragastric administration of Lactobacillus casei expressing transmissible gastroentritis coronavirus spike glycoprotein induced specific antibody production. Vaccine 2005, 23, 1335-1342. [CrossRef]

22. Mohamadzadeh, M.; Duong, T.; Sandwick, S.J.; Hoover, T.; Klaenhammer, T.R. Dendritic cell targeting of Bacillus anthracis protective antigen expressed by Lactobacillus acidophilus protects mice from lethal challenge. Proc. Natl. Acad. Sci. USA 2009, 106, 4331-4336. [CrossRef]

23. Zegers, N.D.; Kluter, E.; van Der Stap, H.; van Dura, E.; van Dalen, P.; Shaw, M.; Baillie, L. Expression of the protective antigen of Bacillus anthracis by Lactobacillus casei: Towards the development of an oral vaccine against anthrax. J. Appl. Microbiol. 1999, 87, 309-314. [CrossRef] [PubMed] 
24. Pant, N.; Hultberg, A.; Zhao, Y.; Svensson, L.; Pan-Hammarstrom, Q.; Johansen, K.; Pouwels, P.H.; Ruggeri, F.M.; Hermans, P.; Frenken, L.; et al. Lactobacilli expressing variable domain of llama heavy-chain antibody fragments (lactobodies) confer protection against rotavirus-induced diarrhea. J. Infect. Dis. 2006, 194, 1580-1588. [CrossRef] [PubMed]

25. Shaw, D.M.; Gaerthé, B.; Leer, R.J.; Van Der Stap, J.G.; Smittenaar, C.; Heijne Den Bak-Glashouwer, M.; Thole, J.E.; Tielen, F.J.; Pouwels, P.H.; Havenith, C.E. Engineering the microflora to vaccinate the mucosa: Serum immunoglobulin $G$ responses and activated draining cervical lymph nodes following mucosal application of tetanus toxin fragment C-expressing lactobacilli. Immunology 2000, 100, 510-518. [CrossRef]

26. Xiu, L.; Sheng, S.; Hu, Z.; Liu, Y.; Li, J.; Zhang, H.; Liang, Y.; Du, R.; Wang, X. Exopolysaccharides from Lactobacillus kiferi as adjuvant enhanced the immuno-protective against Staphylococcus aureus infection. Int. J. Biol. Macromol. 2020, 161, 10-23. [CrossRef]

27. Menzies, B.E.; Kernodle, D.S. Site-directed mutagenesis of the alpha-toxin gene of Staphylococcus aureus: Role of histidines in toxin activity in vitro and in a murine model. Infect. Immun. 1994, 62, 1843-1847. [CrossRef]

28. Menzies, B.E.; Kernodle, D.S. Passive immunization with antiserum to a nontoxic alpha-toxin mutant from Staphylococcus aureus is protective in a murine model. Infect. Immun. 1996, 64, 1839-1841. [CrossRef]

29. Vidgrén, G.; Palva, I.; Pakkanen, R.; Lounatmaa, K.; Palva, A. S-layer protein gene of Lactobacillus brevis: Cloning by polymerase chain reaction and determination of the nucleotide sequence. J. Bacteriol. 1992, 174, 7419-7427. [CrossRef] [PubMed]

30. Maragkoudakis, P.A.; Zoumpopoulou, G.; Miaris, C.; Kalantzopoulos, G.; Pot, B.; Tsakalidou, E. Probiotic potential of Lactobacillus strains isolated from dairy products. Int. Dairy J. 2006, 16, 189-199. [CrossRef]

31. Song, B.F.; Ju, L.Z.; Li, Y.J.; Tang, L.J. Chromosomal insertions in the Lactobacillus casei upp gene that are useful for vaccine expression. Appl. Environ. Microbiol. 2014, 80, 3321-3326. [CrossRef] [PubMed]

32. Lyons, A.B.; Parish, C.R. Determination of lymphocyte division by flow cytometry. J. Immunol. Methods 1994, 171, 131-137. [CrossRef]

33. Han, Y.; Renu, S.; Patil, V.; Schrock, J.; Feliciano-Ruiz, N.; Selvaraj, R.; Renukaradhya, G.J. Mannose-Modified ChitosanNanoparticle-Based Salmonella Subunit OralVaccine-Induced Immune Response and Efficacy in a Challenge Trial in Broilers. Vaccines 2020, 8, 299. [CrossRef] [PubMed]

34. Bettelli, E.; Carrier, Y.; Gao, W.; Korn, T.; Strom, T.B.; Oukka, M.; Weiner, H.L.; Kuchroo, V.K. Reciprocal developmental pathways for the generation of pathogenic effector TH17 and regulatory T cells. Nature 2006, 441, 235-238. [CrossRef] [PubMed]

35. Romagnani, S. Th1/Th2 cells. Inflamm. Bowel Dis. 1999, 5, 285-294. [CrossRef]

36. Bedoya, S.K.; Lam, B.; Lau, K.; Larkin, J., 3rd. Th17 cells in immunity and autoimmunity. Clin. Dev. Immunol. 2013, $2013,986789$. [CrossRef] [PubMed]

37. Zhang, Y.; Zhang, Y.; Gu, W.; Sun, B. TH1/TH2 cell differentiation and molecular signals. Adv. Exp. Med. Biol. 2014, 841, 15-44. [CrossRef]

38. Gao, X.; Ma, Y.; Wang, Z.; Bai, J.; Jia, S.; Feng, B.; Jiang, Y.; Cui, W.; Tang, L.; Li, Y.; et al. Oral immunization of mice with a probiotic Lactobacillus casei constitutively expressing the $\alpha$-toxoid induces protective immunity against Clostridium perfringens $\alpha$-toxin. Virulence 2019, 10, 166-179. [CrossRef] [PubMed]

39. Zhu, J.; Yamane, H.; Paul, W.E. Differentiation of effector CD4 T cell populations (*). Annu. Rev. Immunol. 2010, 28, 445-489. [CrossRef]

40. Lalor, S.J.; McLoughlin, R.M. Memory $\gamma \delta$ T cells-newly appreciated protagonists in infection and immunity. Trends Immunol. 2016, 37, 690-702. [CrossRef]

41. Holtmeier, W. Compartmentalization gamma/delta T cells and their putative role in mucosal immunity. Crit Rev. Immunol. 2003, 23, 473-488. [CrossRef] [PubMed]

42. Dillen, C.A.; Pinsker, B.L.; Marusina, A.I.; Merleev, A.A.; Farber, O.N.; Liu, H.; Archer, N.K.; Lee, D.B.; Wang, Y.; Ortines, R.V.; et al. Clonally expanded $\gamma \delta \mathrm{T}$ cells protect against Staphylococcus aureus skin reinfection. J. Clin. Investig. 2018, 128, $1026-1042$. [CrossRef] [PubMed]

43. Cho, J.S.; Pietras, E.M.; Garcia, N.C.; Ramos, R.I.; Farzam, D.M.; Monroe, H.R.; Magorien, J.E.; Blauvelt, A.; Kolls, J.K.; Cheung, A.L.; et al. IL-17 is essential for host defense against cutaneous Staphylococcus aureus infection in mice. J. Clin. Investig. 2010, 120, 1762-1773. [CrossRef]

44. Mierau, I.; Kleerebezem, M. 10 years of the nisin-controlled gene expression system (NICE) in Lactococcus lactis. Appl. Environ. Microbiol. 2005, 68, 705-717. [CrossRef] [PubMed]

45. Bolotin, A.; Wincker, P.; Mauger, S.; Jaillon, O.; Malarme, K.; Weissenbach, J.; Ehrlich, S.D.; Sorokin, A. The complete genome sequence of the lactic acid bacterium Lactococcus lactis ssp. lactis IL1403. Genome Res. 2001, 11, 731-753. [CrossRef]

46. Duwat, P.; Cesselin, B.; Sourice, S.; Gruss, A. Lactococcus lactis, a bacterial model for stress responses and survival. Int. J. Food Microbiol. 2000, 55, 83-86. [CrossRef]

47. Poquet, I.; Ehrlich, S.D.; Gruss, A. An export-specific reporter designed for gram-positive bacteria: Application to Lactococcus lactis. J. Bacteriol. 1998, 180, 1904-1912. [CrossRef]

48. Ravn, P.; Arnau, J.; Madsen, S.M.; Vrang, A.; Israelsen, H. The development of TnNuc and its use for the isolation of novel secretion signals in Lactococcus lactis. Gene 2000, 242, 347-356. [CrossRef] 
49. Yu, M.; Wang, L.; Ma, S.; Wang, X.; Wang, Y.; Xiao, Y.; Jiang, Y.; Qiao, X.; Tang, L.; Xu, Y.; et al. Immunogenicity of eGFP-marked recombinant Lactobacillus casei against transmissible gastroenteritis virus and porcine epidemic diarrhea virus. Viruses 2017, 9, 274. [CrossRef] [PubMed]

50. Wang, X.; Wang, L.; Huang, X.; Ma, S.; Yu, M.; Shi, W.; Qiao, X.; Tang, L.; Xu, Y.; Li, Y. Oral delivery of probiotics expressing dendritic cell-targeting peptide fused with porcine epidemic diarrhea virus COE Antigen: A promising vaccine strategy against PEDV. Viruses 2017, 9, 312. [CrossRef]

51. Ma, S.; Wang, L.; Huang, X.; Wang, X.; Chen, S.; Shi, W.; Qiao, X.; Jiang, Y.; Tang, L.; Xu, Y.; et al. Oral recombinant Lactobacillus vaccine targeting the intestinal microfold cells and dendritic cells for delivering the core neutralizing epitope of porcine epidemic diarrhea virus. Microb. Cell Fact. 2018, 17, 20. [CrossRef] [PubMed]

52. Elias, P.M.; Hatano, Y.; Williams, M.L. Basis for the barrier abnormality in atopic dermatitis: Outside-inside-outside pathogenic mechanisms. J. Allergy Clin. Immunol. 2008, 121, 1337-1343. [CrossRef] [PubMed]

53. Hong, S.W.; Choi, E.B.; Min, T.K.; Kim, J.H.; Kim, M.H.; Jeon, S.G.; Lee, B.J.; Gho, Y.S.; Jee, Y.K.; Pyun, B.Y.; et al. An important role of $\alpha$-hemolysin in extracellular vesicles on the development of atopic dermatitis induced by Staphylococcus aureus. PLoS ONE 2014, 9, e100499. [CrossRef]

54. Song, L.; Hobaugh, M.R.; Shustak, C.; Cheley, S.; Bayley, H.; Gouaux, J.E. Structure of staphylococcal alpha-hemolysin, a heptameric transmembrane pore. Science 1996, 274, 1859-1866. [CrossRef] [PubMed]

55. Kennedy, A.D.; Bubeck Wardenburg, J.; Gardner, D.J.; Long, D.; Whitney, A.R.; Braughton, K.R.; Schneewind, O.; DeLeo, F.R. Targeting of alpha-hemolysin by active or passive immunization decreases severity of USA300 skin infection in a mouse model. J. Infect. Dis. 2010, 202, 1050-1058. [CrossRef]

56. Bubeck Wardenburg, J.; Schneewind, O. Vaccine protection against Staphylococcus aureus pneumonia. J. Exp. Med. 2008, 205, 287-294. [CrossRef]

57. Seegers, J.F. Lactobacilli as live vaccine delivery vectors: Progress and prospects. Trends Biotechnol. 2002, 20, 508-515. [CrossRef]

58. Mao, R.; Zhou, K.; Han, Z.; Wang, Y. Subtilisin QK-2: Secretory expression in Lactococcus lactis and surface display onto gram-positive enhancer matrix (GEM) particles. Microb. Cell Fact. 2016, 15, 80. [CrossRef]

59. Mao, R.; Wu, D.; Hu, S.; Zhou, K.; Wang, M.; Wang, Y. Secretory expression and surface display of a new and biologically active single-chain insulin (SCI-59) analog by lactic acid bacteria. Appl. Environ. Microbiol. 2017, 101, 3259-3271. [CrossRef]

60. Zhang, Q.; Zhong, J.; Liang, X.; Liu, W.; Huan, L. Improvement of human interferon alpha secretion by Lactococcus lactis. Biotechnol. Lett. 2010, 32, 1271-1277. [CrossRef]

61. Kidd, P. Th1/Th2 balance: The hypothesis, its limitations, and implications for health and disease. Altern. Med. Rev. 2003, 8, 223-246.

62. Magram, J.; Connaughton, S.E.; Warrier, R.R.; Carvajal, D.M.; Wu, C.-y.; Ferrante, J.; Stewart, C.; Sarmiento, U.; Faherty, D.A.; Gately, M.K. IL-12-deficient mice are defective in IFN- $\gamma$ production and type 1 cytokine responses. Immunity 1996, 4, 471-481. [CrossRef]

63. VanCott, J.L.; Staats, H.F.; Pascual, D.W.; Roberts, M.; Chatfield, S.N.; Yamamoto, M.; Coste, M.; Carter, P.B.; Kiyono, H.; McGhee, J.R. Regulation of mucosal and systemic antibody responses by $\mathrm{T}$ helper cell subsets, macrophages, and derived cytokines following oral immunization with live recombinant Salmonella. J. Immunol. 1996, 156, 1504-1514. [PubMed]

64. Harrington, L.E.; Hatton, R.D.; Mangan, P.R.; Turner, H.; Murphy, T.L.; Murphy, K.M.; Weaver, C.T. Interleukin 17-producing $\mathrm{CD}^{+}$effector T cells develop via a lineage distinct from the T helper type 1 and 2 lineages. Nat. Immunol. 2005, 6, 1123-1132. [CrossRef] [PubMed]

65. Quan, F.S.; Compans, R.W.; Kang, S.M. Oral vaccination with inactivated influenza vaccine induces cross-protective immunity. Vaccine 2012, 30, 180-188. [CrossRef]

66. Worbs, T.; Bode, U.; Yan, S.; Hoffmann, M.W.; Hintzen, G.; Bernhardt, G.; Förster, R.; Pabst, O. Oral tolerance originates in the intestinal immune system and relies on antigen carriage by dendritic cells. J. Exp. Med. 2006, 203, 519-527. [CrossRef] [PubMed]

67. Licciardi, P.V.; Tang, M.L. Vaccine adjuvant properties of probiotic bacteria. Discov. Med. 2011, 12, 525-533. [PubMed]

68. Zhang, Z.; Lv, J.; Pan, L.; Zhang, Y. Roles and applications of probiotic Lactobacillus strains. Appl. Environ. Microbiol. 2018, 102, 8135-8143. [CrossRef] [PubMed]

69. Aktas, B.; De Wolfe, T.J.; Safdar, N.; Darien, B.J.; Steele, J.L. The impact of Lactobacillus casei on the composition of the cecal microbiota and innate immune system is strain specific. PLoS ONE 2016, 11, e0156374. [CrossRef]

70. Sisto, A.; Luongo, D.; Treppiccione, L.; De Bellis, P.; Di Venere, D.; Lavermicocca, P.; Rossi, M. Effect of Lactobacillus paracasei culture filtrates and artichoke polyphenols on cytokine production by dendritic cells. Nutrients 2016, 8, 635. [CrossRef]

71. Su, Y.; Chen, X.; Liu, M.; Guo, X. Effect of three lactobacilli with strain-specific activities on the growth performance, faecal microbiota and ileum mucosa proteomics of piglets. J. Anim. Sci. Biotechnol. 2017, 8, 52. [CrossRef]

72. Bagnoli, F.; Bertholet, S.; Grandi, G. Inferring reasons for the failure of Staphylococcus aureus vaccines in clinical trials. Front. Cell Infect. Microbiol. 2012, 2, 16. [CrossRef] [PubMed]

73. Proctor, R.A. Challenges for a universal Staphylococcus aureus vaccine. Clin. Infect. Dis. 2012, 54, 1179-1186. [CrossRef] [PubMed]

74. Scully, I.L.; Liberator, P.A.; Jansen, K.U.; Anderson, A.S. Covering all the bases: Preclinical development of an effective Staphylococcus aureus vaccine. Front. Immunol. 2014, 5, 109. [CrossRef] 
75. Kim, S.R.; Lee, K.S.; Park, S.J.; Min, K.H.; Lee, K.Y.; Choe, Y.H.; Lee, Y.R.; Kim, J.S.; Hong, S.J.; Lee, Y.C. PTEN downregulates IL-17 expression in a murine model of toluene diisocyanate-induced airway disease. J. Immunol. 2007, 179, 6820-6829. [CrossRef] [PubMed]

76. Miossec, P.; Kolls, J.K. Targeting IL-17 and TH17 cells in chronic inflammation. Nat. Rev. Drug Discov. 2012, 11, 763-776. [CrossRef] [PubMed]

77. Song, X.; He, X.; Li, X.; Qian, Y. The roles and functional mechanisms of interleukin-17 family cytokines in mucosal immunity. Cell Mol. Immunol. 2016, 13, 418-431. [CrossRef] [PubMed]

78. Cheng, P.; Liu, T.; Zhou, W.Y.; Zhuang, Y.; Peng, L.S.; Zhang, J.Y.; Yin, Z.N.; Mao, X.H.; Guo, G.; Shi, Y.; et al. Role of gamma-delta $\mathrm{T}$ cells in host response against Staphylococcus aureus-induced pneumonia. BMC Immunol. 2012, 13, 38. [CrossRef] 